\title{
Simulation with Computational Fluid Dynamics of Succinic Acid and Co- Product Biorefinery Process
}

\author{
Pierre Wensel, Liang Yu and Shulin Chen* \\ Department of Biological Systems Engineering, Washington State University, Pullman, WA 99164,USA
}

\begin{abstract}
Succinic acid is a di-carboxylic acid with tremendous future market potential, and there is increasing interest to produce it from microorganisms using cheap renewable resources like biomass. However, commercialization of bio-succinic acid is currently challenged by limited profitability of processes devoted solely to succinic acid, high downstream process costs, and minimal available industrial-scale simulation. To address these limitations, a novel industrial-scale biorefinery process to convert corn-stover into succinic acid and co-products was simulated using an integrated mathematical model developed from reported laboratory-scale experimental data. The upstream section of the biorefinery featured handling, pre-treatment, conversion, and separation of corn stover feedstock into a liquid fraction for ethanol processing and a solids fraction containing mostly cellulose that was further hydrolyzed into glucose for succinic acid processing. Subsequent units of operation were then simulated for a baseline process: Microfiltration was used to remove residual insoluble lignin, and glucose was then continuously fermented by the strain M. Succiniciproducens MBEL55E to produce succinate and by-products acetate, lactate, and formate. Additional steps to recover and purify succinic acid included cell microfiltration for cell removal, moving-bed adsorption for sugar removal and decolorization, nanofiltration for separation of succinate primarily from other salts, ion exchange for acidification and purification, and finally crystallization. The finite volume method of Computational Fluid Dynamics (CFD) was coupled with kinetic, stochiometric, mass, and energy balance equations to simulate the effects of inlet temperature impeller speed, diameter, and spacing, as well as inlet temperature and fermentor volume, on fermentor cooling jacket heat transfer area. Predicted dissolved $\mathrm{CO}_{2}$ concentrations in the fermentor were in agreement with those in literature. The effects of microfiltration recirculation rate, microfiltration stage numbers, and adsorber sorbent particle diameter on dimensional requirements and power consumption were additionally evaluated. Yields and estimated volume and area requirements for units of operation were obtained for the baseline process and for those involving the simulated variable changes. This work represents the first reported industrial-scale bio-succinic acid process model.
\end{abstract}

Key words: Succinic acid; Biorefinery; Manheima succiniciproducens; Process simulation

\section{Introduction}

Succinic acid is a di-carboxylic acid which can be used as a $\mathrm{C} 4$ chemical building-block for manufacturing industrially valuable chemicals like adipic acid, N-methyl pyrrolidinone, 2-pyrrolidinone, succinate salts, 1,4-butanediol, maleic anhydride, tetrahydrofuran and gamma-butyrolactone, as well as ion-chelators, surfactants, detergents, synthetic resins, biodegradable polymers, pharmaceuticals, antimicrobials, food acidualants, flavor-enhancers, and green solvents [1-3]. Current succinic acid production ranges from 25,000-36,000 t/year, and market price ranges from $\$ 5.90-9.00$ (U.S.)/kg depending on purity $[3,4]$. Succinic acid market and price were predicted to range from 180,000$27,000,000 \mathrm{t} /$ year $[1,5]$, and from $\$ 0.50-1.50$ (U.S.) $/ \mathrm{kg}$, respectively $[2,5]$.

Conventional production of succinic acid involves chemically processing fossil-based resources like petroleum through oxidation of nbutane or benzene via maleic anhydride, followed by hydrolysis and dehydrogenation $[2,6]$. However, there is increased commercial and scientific interest to instead produce succinic acid from microorganisms using cheaper renewable resources like biomass. In 2004, the U.S. Department of Energy designated succinic acid as one of the top valueadded chemicals from biomass [7]. Prospects of global bio-based succinic acid markets motivated companies Bioamber, DSM and Roquette, BASF and CSM, and Myriant to announce construction of new plants since 2010 [8-10]. We previously demonstrated a process involving pretreatment and hydrolysis of inexpensive and renewable ligno-cellulosic waste and residue like corncob from agricultural and food industries to yield substrates for microbial fermentative production of succinic acid and co-products [11].
Commercialization of bio-succinic acid is nonetheless currently challenged by limited profitability when a plant is devoted solely to succinic acid [5]. Succinic acid production should therefore occur in an integrated biorefinery, where co-production of ethanol, other carboxylic acids, and on-site steam and electricity via processing of recovered lignin residues enhance profitability. Commercialization is also challenged by high downstream costs associated with isolation, purification, and sterilization of end-products accounting for up to $80 \%$ of total production cost [12]. For example, succinic acid precipitation by $\mathrm{Ca}^{2+}-$ containing species results in excessive sludge waste and also adversely affects the fermented cellular metabolism and cell membrane fluidity and permeability [12-14]. Reactive extraction with tri-n-octalamine (TOA) [15] can remove glucose but suffers from organic solvent toxicity and waste. A promising batch laboratory-scale process involving four-acid products Actinobacillus succinogenes fermentation and downstream centrifugation, filtration, activated carbon adsorption, cationexchange chromatography, vacuum distillation, crystallization, filtra-

*Corresponding author: Shulin Chen, Department of Biological Systems Engineering, Washington State University, Pullman, WA 99164, USA, Tel: 509-3353743; Fax: 509-335-2722; E-mail: chens@wsu.edu

Received November 01, 2011; Accepted December 08, 2011; Published December 10, 2011

Citation: Wensel P, Yu L, Chen S (2011) Simulation with Computational Fluid Dynamics of Succinic Acid and Co-Product Biorefinery Process. J Bioprocess Biotechniq S2:002 doi:10.4172/2155-9821.S2-002

Copyright: (c) 2011 Wensel P, et al. This is an open-access article distributed under the terms of the Creative Commons Attribution License, which permits unrestricted use, distribution, and reproduction in any medium, provided the original author and source are credited. 
tion, and drying achieved an $89.5 \%$ succinic acid yield from substrate and $99 \%$ purity [8]. However, a commercial-scale biorefinery should instead recover valuable and volatile pyruvic, acetic, and formic acid by-products rather than eliminate them at $60^{\circ} \mathrm{C}$ and $\mathrm{pH} 4$ with vacuum distillation [16]. In contrast, a nanofiltration process achieved sharp and non-destructive separation of succinate from a quartenary mixture containing lactate as opposed to pyruvate co-product but was not integrated with other purification steps [17].

Electrodialysis has been effectively used to concentrate and acidify succinic acid and other organic acids due to its environmental benignity, scalability, and ability to achieve high purity [18-27]. For instance, de-salting electrodialysis removed impurities and achieved a suitably concentrated, but undersaturated $(<25 \%$ weight $)$ succinate solution for one process [22]. This was then converted into a supersaturated succinic acid solution where ionized succinic acid was converted into undisassociated succinic acid by passing it through a water-splitting bipolar electrodialysis unit, from which an alkali $\mathrm{NaOH}$ stream was recycled to neutralize produced acids [22].Conventional electrodialysis was similarly integrated to a feed containing concentrated organic salt sodium gluconate to a bipolar membrane as a way to increase stability and limit a decrease in current efficiency and dramatic increase in energy consumption that frequently results at a high organic salts conversion rate in bipolar membranes due to salt depletion in feed compartments and organic acids diffusion [25]. Integration resulted in an apparent current efficiency higher than $100 \%$, low energy consumption, and a predicted process cost of $\$ 0.31 \mathrm{~kg}^{-1}$, which was less than the $\$ 0.39 \mathrm{~kg}^{-1}$ for the bipolar membrane [25]. Another process involving a succinic acid fermentation by E.coli strain ATCC202021 used first nanofiltration and then desalting electrodialysis to further concentrate and purify succinate salts and remove small and large molecular weight nonionic or weakly ionic compounds like sugars [26]. Severe membrane fouling was here alleviated by cleaning-in-place, reducing protein content in the fermentation broth, and raising its $\mathrm{pH}$ prior to microfiltration to denature the majority of proteins [26]. A mono-polar electrodialysis unit was also integrated with a continuous cell recycle fermentor for the production of succinic acid by A. succinogenes to continuously remove succinate and acetate from the permeate and recycle an organic acids-depleted solution back to the fermentor [19]. Compared to the cell recycle fermentor, this resulted in a five-fold increase in succinate concentration to $83 \mathrm{~g} / \mathrm{L}$ at a high average succinate yield of $1.35 \mathrm{~mol} /$ mol and a slightly lower volumetric productivity of $10.4 \mathrm{~g} / \mathrm{L}^{-1} \mathrm{~h}^{-1}[19]$.

Nonetheless, a comparison between the technical feasibility of electrodialysis and that of other downstream methods must consider various factors like the cost of membrane and electrical energy consumption $[8,13,18]$. This may depend on purity levels and concentration profile, which in turn depends on water transport, the co-ion leakages through homopolar membranes, and the current density [28]. Also, to achieve higher succinic product fermentation concentrations than those obtained with $\mathrm{NaOH}, \mathrm{MgCO}_{3}$ has not only been used as a (1) $\mathrm{pH}$ controlling alkaline neutralizer to prevent acid product inhibition, but also as (2) a more soluble source of inorganic carbon than $\mathrm{CO}_{2}$ gas requiring expensive compression, and (3) as a source of the co-factor $\mathrm{Mg}^{2+}$ for the enzyme PEP carboxykinase that is essential for succinate synthesis [14]. The inability of downstream electrodialysis membranes for acidification and purification to effectively handle divalent $\mathrm{Mg}^{2+}$ cation-containing species was therefore considered a major limitation [2]. Exploitation of the Donnan charge exclusion and the fixed charges of most nanofiltration membranes was also deemed more appropriate than electrodialysis when separating ionic by-product organic acid salts from succinate and when separating salts from organic electrolytes typically present in effluents produced by salt-generating reactions or by acid- or alkali-generating reactions followed by neutralization [ 17 , 27]. Furthermore, the process costs and competitiveness of using either electrodialysis with bipolar membrane or ion exchange to acidify the carboxylic glucamonic acid were theoretically calculated by introducing two factors for environmental pollution and bipolar membrane prices and then compared [18]. Although these processes could be integrated to reduce environmental factors, results indicated that total process cost for ion-exchange was $\$ 0.057 \mathrm{~kg}^{-1}$ and less than that for bipolar membrane electrodialysis $\left(\$ 0.085-0.407 \mathrm{~kg}^{-1}\right)$ [18].

There is also limited reported industrial-scale process simulation and economic analysis for bio-succinic acid fermentation, recovery, and purification [29]. For instance, experimentally-derived succinic acid crystal growth and nucleation kinetics [30], succinic acid and lactic acid liquid-solid sorbent equilibria [31], and rejection coefficients at specified transmembrane pressure and flux [17] were not then used to simulate integrated large-scale crystallizers, ion exchangers, or nanofilters, respectively. Model-predicted $\mathrm{CO}_{2}$ solubility and its experimentally observed effects on growth and succinic acid production during M. succiniciproducens fermentation were reported [32]. Kinetics for growth, glucose consumption, carboxylic acid production, and product and substrate inhibition were also simulated and experimentally verified for small-scale batch M. succiniciproducens MBEL55E [6] and A. succinogenes [33] fermentations. However, a robust commercial-scale process model should involve continuous fermentors since their productivity will be at least 5.3 times greater than that of batch fermentors [34]. A continuous fermentor integrated with monopolar electrodialysis membrane for removal of cells and inhibitory levels of acetate and lactate was reported but not modeled [19].

A robust commercial-scale process model should also account for hydrodynamic phenomena in a continuous fermentor and its impact on heat and mass transfer, temperature and nutrient uniformity, and, when applicable, cell shear-sensitivity. For instance, growth inhibition of M. succiniciproducens MBEL55E was observed beyond an accumulated carboxylic acid concentration of $17.23 \mathrm{~kg} / \mathrm{m}^{3}$ in a small 5-L batch fermentor [6]. Growth inhibition was also observed below a dissolved $\mathrm{CO}_{2}$ concentration of $8.74 \mathrm{mM}$ in a small 6.6-L batch M. succiniciproducens fermentor [32]. Overcoming these pilot-scale limitations at more heterogeneous commercial scales via, for instance, addition of neutralizing $\mathrm{MgCO}_{3}$ base and carbon source and higher inlet $\mathrm{CO}_{2}$ partial pressures and agitation impeller speeds will be more systematically achieved by feeding and sparging strategies derived from hydrodynamic studies characterizing mixing times and gas-liquid mass transfer coefficients.

We here describe and simulate a novel commercial-scale succinic acid biorefinery process featuring upstream corn-stover pre-treatment, hydrolysis, and cross-flow microfiltration and centrifugation for lignin recovery to yield sugars both for a co-ethanol fermentation and continuous M. succiniciproducens glucose fermentation for succinic acid, lactic, acetic, and formic acids production. These are then recoverable by microfiltration for cell removal, adsorption for decolorization and glucose removal, nanofiltration for non-destructive separation of succinate, ion exchange chromatography, crystallization, filtration, and drying. A baseline process was assumed, but the effects of microfiltration recirculation rate, microfiltration stage numbers, fermentation productivity kinetics, and adsorber sorbent particle diameter on dimensional requirements and power consumption for capital and operating cost estimation were simulated. Effects of impeller speed and inlet temperature on fermentor power and cooling jacket heat transfer area were also simulated by coupling mass and energy balances and experimentally- 
Citation: Wensel P, Yu L, Chen S (2011) Simulation with Computational Fluid Dynamics of Succinic Acid and Co-Product Biorefinery Process. J Bioprocess Biotechniq S2:002 doi:10.4172/2155-9821.S2-002

Page 3 of 17

derived kinetics to the finite volume method of Computational Fluid Dynamics (CFD).

CFD involves numerical solution of conservation equations for mass, momentum and energy in a flow geometry of interest, together with additional subsidiary sets of equations reflecting the considered problem [35]. Flow optimization via this tool represents significant potential savings in time and resources and increased profitability for a low profit margin, bio-commodity succinic acid process [35] by providing more data than physical trials and reducing the need for numerous and expensive experiments with prototype fermentors and probes. This is the first reported process simulation for industrial-scale bio-succinic acid production.

\section{Method}

Microsoft Excel v. 2007 software was used for calculations associated with process mass and energy balances, unit simulation via variable changes, and cost and sensitivity analysis. CFD numerical procedure was conducted with commercial code FLUENT (v.6.3.26)[36]. The simulated biorefinery process is shown (Figure 1). Description of major process streams are listed (Table 1). The feedstock was corn stover containing approximately $40-45 \%$ cellulose, $30-35 \%$ hemicellulose, and $10-20 \%$ lignin [11].The biorefinery was located in Iowa, a state ac- counting for $19 \%$ of total U.S. corn production having infrastructure to fulfill biorefinery requirement for co-production of corn-based ethanol. Capacity of 2,500 tons (wet basis) of corn stover/day was selected according to a National Renewable Energy Laboratory (NREL) model where raw material was collected within a $50 \mathrm{~km}$ radius [37]. This was the basis for the mass and energy balances and flow rates to simulate the succinic acid process units ranging from lignin microfiltration to crystallization. Unlike for plants devoted solely to ethanol fuel production, the generalized energy balance did not aim to show the extent that corn stover was converted into fuel energy since acid products were not fuels. Instead, energy losses and stream energy content were estimated:

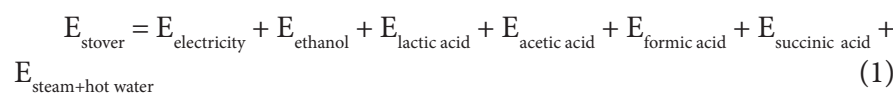

Energy content was determined by multiplying mass flux by the corresponding High Heating Values (HHV) of 16, 29.7, 21.1, and 32.1 $\mathrm{MJ} / \mathrm{kg}$ for corn stover, ethanol, lignin, and for each of the carboxylic acid products, respectively [38]. Electricity requirement was determined from estimates of electrical motor power consumption (i.e. for fermentor and crystallizer agitator), control systems, etc. Thermal energy requirement was determined from individual unit energy balances.



Figure 1: General flow diagram for succinic acid biorefinery. 


\begin{tabular}{|c|c|}
\hline Major Process Stream ID & Description \\
\hline 1 & Corn Stover Feedstock (Dry Basis) \\
\hline 2 & Corn Stover Feedstock Water Moisture Content \\
\hline 3 & Losses \\
\hline 4 & Supplemented Water \\
\hline 5 & Shredded Corn Stover \\
\hline 6 & Sulfuric Acid \\
\hline 7 & Steam \\
\hline 8 & Pre-treated Stover 1 \\
\hline 9 & Steam \\
\hline 10 & Pre-treated Stover 2 \\
\hline 11 & Supplemented Water \\
\hline 12 & Liquid Hemicellulose Fraction to Ethanol Plant \\
\hline 13 & Solids Cellulose Fraction to Succinic Acid Plant \\
\hline 14 & Calcium Hydroxide \\
\hline 15 & Supplemented Water \\
\hline 16 & Cellulose Fraction to Sacharification \\
\hline 17 & Hydrolysate \\
\hline 18 & Lignin Microfiltration Retentate \\
\hline 19 & $\begin{array}{l}\text { Concentrated Lignin to Steam and Power Genera- } \\
\text { tion }\end{array}$ \\
\hline 20 & Centrifuged Retentate Flowthrough \\
\hline 21 & Lignin Microfiltration Permeate \\
\hline 22 & Combined Permeate Feed to Fermentation \\
\hline 23 & $\begin{array}{l}\text { Fermentation Product Streams (Cells, succinate, } \\
\text { acetate, formate, and lactate) }\end{array}$ \\
\hline 24 & Cell Microfiltration Stage\#1 Permeate \\
\hline 25 & Cell Microfiltration Stage\#2 Retentate \\
\hline 26 & Cell Microfiltration Stage\#1 Permeate \\
\hline 27 & Cell Microfiltration Stage\#2 Retentate \\
\hline 28 & $\begin{array}{l}\text { Combined Permeate Feed to Adsorption and } \\
\text { Desorption }\end{array}$ \\
\hline 29 & Recovered Glucose Sugars \\
\hline 30 & Regenerating Hot Water Solution \\
\hline 31 & Nanofiltration Feed \\
\hline 32 & Nanofiltration Permeate \\
\hline 33 & Nanofiltration Retentate \\
\hline 34 & Hot Water Regeneration Solution \\
\hline 35 & Lactic Acid Flowthrough for Further Processing \\
\hline 36 & Stripped Lactic Acid Eluant \\
\hline 37 & Vented Water Vapor \\
\hline 38 & $\begin{array}{l}\text { Mother Liquor from Circulating Magma for Further } \\
\text { processing }\end{array}$ \\
\hline 39 & Succinic Acid Crystal \\
\hline
\end{tabular}

Table 1: Description of major process flow streams.

\section{Upstream processes including lignin microfiltration and cen- trifugation}

Upstream processes ranging from raw material corn stover feed handling to sacharification resembled those of a previous corn-based ethanol biorefinery [37], with the following major modifications and simplifying assumptions: First, pre-hydrolysis, the most thermal energy-consuming plant process, involved $1.2 \%$ diluted sulfuric acid and pressurized steam at $245^{\circ} \mathrm{C}$, and 13.6 bar instead of ammonia fiber expansion (AFEX) to enable separation of liquid hemicellulose streams composed primarily of pentoses for ethanol fermentation and solid cellulose streams composed primarily of hexoses for glucose-based succinic acid fermentation. Second, the process included single-stage cross-flow tubular microfiltration units and centrifuge to remove and recover insoluble lignin from hydrolysate for combustion in a boiler and extra biorefinery steam and electricity.
Lignin-generated steam flow rate was calculated from lignin HHV, a boiler thermal efficiency of 0.65 , specific enthalpy of steam at prehydrolysis conditions, and recovered lignin flow rate. For microfiltration, all insoluble lignin was retained, and the amount of glucose substrate partitioned to the retentate and permeate was $5 \%$ and $95 \%$ by mass, respectively. Retentate lignin concentration was specified based on a reported level $300 \mathrm{~g} / \mathrm{L}$ of soluble lignin ultra-filtered in a pulp and mill plant [39]. To avoid rapid membrane caking or fouling, recirculation rate of $6 \mathrm{~m} / \mathrm{s}$ was used for the baseline process but also varied for simulation, and specified inner diameter and length dimensions of the tubular module ensured turbulent Reynold's number. Assuming $40 \mu \mathrm{m}$ diameter spherical and insoluble lignin particles, inertial-lift theory [40] was used to calculate constant critical permeate flux representing $66 \%$ of the steady-state permeate flux [41] as follows:

$$
J_{c}=\frac{0.024 \rho_{p} r^{3} \gamma_{w}^{2}}{\mu_{p}}
$$

where $J_{c}$ is critical permeate flux $(\mathrm{m} / \mathrm{s}), \rho_{p}$ is permeate density $\left(\mathrm{kg} / \mathrm{m}^{3}\right)$, $\mu_{p}$ is permeate viscosity $\left(\mathrm{Pa}^{*} \mathrm{~s}\right), \mathrm{r}$ is lignin particle radius $(\mathrm{m})$, and $\gamma_{\mathrm{w}}$ is tubular wall shear rate $\left(\mathrm{s}^{-1}\right)$. Microfiltration membrane area requirement was the ratio of mass balance-derived permeate flow rate to critical flux. Microfiltration power consumption was calculated [42]:

$$
P_{\text {micro-1 }}=\frac{0.04 \mathrm{Re}^{-0.25} A_{\text {micro- } 1} U_{\text {micro- } 1}^{3} \rho_{p}}{\eta}
$$

where $\mathrm{P}_{\text {micro-1 }}$ is pump power consumption $(\mathrm{J} / \mathrm{s}), \mathrm{U}_{\text {micro-1 }}$ is recirculation rate $(\mathrm{m} / \mathrm{s}), \eta_{p}$ is pump efficiency (Dimensionless), $\mathrm{A}_{\text {micro- } 1}$ is the area requirement $\left(\mathrm{m}^{2}\right)$, and Re is Reynold's Number (Dimensionless) calculated as follows:

$$
\operatorname{Re}=\frac{U_{\text {micro-1 }}^{3} d_{\text {micro-1 }} \rho_{p}}{\mu_{p}}
$$

Where $\mathrm{d}_{\text {micro-1 }}$ is tube inner diameter $(\mathrm{m})$. The microfiltration retentate was then centrifuged to further de-water and concentrate its lignin prior to boiler combustion. A Sigma Factor $\Sigma$ specifying disk-type centrifuge area requirement was calculated [40]

\section{Fermentation}

The centrifuged and de-lignified retentate liquid stream containing glucose was then combined with microfiltration permeate, sterilized and cooled in external heat exchanger, and introduced to the continuous fermentor for succinic acid and co-production of lactic acid, acetic acid, and formic acid. The baseline process used the available batch kinetic parameters of $M$. succiniciproducens MBEL55E [6], a gramnegative capnophilic bacterium isolated from bovine rumen [32]. Succinic acid is metabolically both an intermediate of the reductive TCA cycle and fermentative end product for this and other anaerobic and facultative microorganisms [32]. Some other strains [3] have reportedly higher succinic acid yields and titers than M. succiniciproducens (Table 2). Some even have the flexibility of C5 and C6 sugar uptake [11] and Simultaneous Sacharification and Fermentation (SSF) [43]. However, their parameters were either unreported or less usable because yield and production terms were convoluted into single terms [33]. Nonetheless, the effect of substituting in an A. succinogenes succinic acid productivity term on overall succinic acid yield was simulated.

An algorithm depicting the CFD-coupled model to predict the effect of impeller speed and inlet temperature on fermentor cooling jacket heat transfer area requirement is illustrated (Figure 2). To initially determine fermentor dimensions for such CFD simulation, an idealized Continuously Stirred Tank Reactor (CSTR) at steady-state 
Citation: Wensel P, Yu L, Chen S (2011) Simulation with Computational Fluid Dynamics of Succinic Acid and Co-Product Biorefinery Process. J Bioprocess Biotechniq S2:002 doi:10.4172/2155-9821.S2-002

Page 5 of 17

\begin{tabular}{|l|c|c|c|c|c|}
\hline Microorganims & $\mathrm{Y}(\mathrm{g} / \mathrm{g}$ glc) & $\begin{array}{l}q_{\text {suuc }}(\mathrm{g} / \\
\mathrm{gDCW} / \mathrm{h})\end{array}$ & $r_{\text {succ }}(\mathrm{g} / / \mathrm{h})$ & Titer $(\mathrm{g} / \mathrm{l})$ & $\begin{array}{l}\text { Residence- } \\
\text { Time }(\mathrm{h})\end{array}$ \\
\hline C. glutamicum & 0.92 & 0.06 & 3.17 & 146 & 46 \\
\hline A. succinogenes & 0.82 & N.D. & 1.36 & 105.8 & 78 \\
\hline M. succiniciproducens & 0.76 & 0.72 & 1.80 & 52.4 & 30 \\
\hline
\end{tabular}

Table 2: Yields, reaction rates, and titers for C. glutamicum, A. succinogenes, and M. succiniciproducens.



Figure 2: Algorithm of coupled CFD fermentor simulation

with equivalent inlet and outlet flow rates was assumed. The fermentor was assumed to be cylindrical, free of headspace and internals, and sparged at the bottom by pure $\mathrm{CO}_{2}$ gas from a clean, filtered, and recycled exhaust waste stream integrated from biorefinery ethanol fermentors. Steady-state liquid-phase mass balances for the component cell biomass, substrate, and carboxylic acid products using the available batch kinetic parameters of M. succiniciproducens MBEL55E [6] were therefore developed:

\section{Viable cell liquid-phase mass balance:}

$$
\frac{d X_{s s}}{d t}=0=\frac{F\left(X_{0}-X_{s s}\right)}{V_{L}}+\mu X_{s s}-k_{d} X_{s s}
$$

where is steady-state cell biomass concentration $\left(\mathrm{kg} \mathrm{DCW} / \mathrm{m}^{3}\right)$, is initial feed cell biomass concentration $\left(\mathrm{kg} \mathrm{DCW} / \mathrm{m}^{3}\right), \mu$ is specific growth rate $\left(\mathrm{s}^{-1}\right), F$ is inlet/outlet volumetric flow rate $\left(\mathrm{m}^{3} / \mathrm{s}\right), V_{L}$ is fermentor liquid volume $\left(\mathrm{m}^{3}\right)$, and is specific death rate $\left(\mathrm{s}^{-1}\right)$. Omitting substrate and product inhibition terms [6] and assuming Monod kinetics to avoid multiple non-washout steady-states [34], was further expressed as:

$$
\mu=\frac{\mu_{\max } S_{s s}}{K_{S}+S_{s s}}
$$

where $\mu_{\max }$ is maximum specific growth rate $\left(\mathrm{s}^{-1}\right)$, is glucose substrate half-saturation constant $\left(\mathrm{kg} / \mathrm{m}^{3}\right)$, and $S_{S S}$ is steady-state glucose substrate concentration $\left(\mathrm{kg} / \mathrm{m}^{3}\right)$. Because feed was previously sterilized, $\mathrm{X}_{\mathrm{o}}=0 \mathrm{~kg} /$ $\mathrm{m}^{3}$. The recycle of cells back to the fermentor after downstream microfiltration recovery was for simplicity not simulated. A shear-dependent death rate term coupled with CFD simulation parameters was included as follows [44]:

$$
k_{d}=\frac{c N_{\text {impeller }}^{2.25} d_{\text {cell }} D_{\text {impeller }}^{3.75}}{v_{l}^{1.25} V_{L}^{0.75}}
$$

where $N_{\text {impeller }}$ is rotational impeller speed (rps), $d_{\text {cell }}$ is equivalent diameter for rodococcal M. succiniciproducens $(\mathrm{m}), D_{\text {impeller }}$ is impeller diameter $(\mathrm{m})$, is dynamic viscosity $\left(\mathrm{m}^{2} / \mathrm{s}\right), V_{L}$ is fermentor liquid volume $\left(\mathrm{m}^{3}\right)$, and $\mathrm{c}$ is cell-dependent death rate constant $\left(\mathrm{m}^{3} / \mathrm{s}\right)$. However, $\mathrm{k}_{\mathrm{d}} \sim 0$, as $M$. succiniciproducens, unlike animal cells, likely had a very small death rate constant since E.coli were reportedly damaged only at shear rates exceeding $1250 \mathrm{~Pa}$ [45].

\section{Carboxylic acids product liquid-phase mass balances:}

$$
\begin{aligned}
& \frac{d P_{S A s s}}{d t}=0=\alpha_{S A} \mu X_{s s}+\beta_{S A} X_{s s}-\frac{F\left(P_{S A s s}\right)}{V_{L}} \\
& \frac{d P_{A A s s}}{d t}=0=\alpha_{A A} \mu X_{s s}+\beta_{A A} X_{s s}-\frac{F\left(P_{A A s s}\right)}{V_{L}} \\
& \frac{d P_{L A s s}}{d t}=0=\alpha_{L A} \mu X_{s s}+\beta_{L A} X_{s s}-\frac{F\left(P_{L A s s}\right)}{V_{L}} \\
& \frac{d P_{F A s s}}{d t}=0=\alpha_{F A} \mu X_{s s}+\beta_{F A} X_{s s}-\frac{F\left(P_{F A s s}\right)}{V_{L}}
\end{aligned}
$$

where $P_{S A s s}, P_{A A s s}, P_{L A s s}$, and $P_{F A s s}$ are steady-state concentrations of succinic acid, lactic acid, acetic acid, and formic acid concentrations, respectively $\left(\mathrm{kg} / \mathrm{m}^{3}\right), \alpha_{S A}, \alpha_{A A}, \alpha_{L A}$, and $\alpha_{F A}$ are growth-associated productivity terms for succinic acid, acetic acid, lactic acid, and formic acid, respectively $(\mathrm{kg} / \mathrm{kg}), \beta_{S A}, \beta_{A A}, \beta_{L A}$ and $\beta_{F A}$ are non-growth associated productivity terms for succinic acid, acetic acid, lactic acid, and formic acid, respectively $(\mathrm{kg} / \mathrm{kg})$.

\section{Glucose substrate liquid-phase mass balance:}

$$
\begin{aligned}
& \frac{d S_{s s}}{d t}=0=\frac{F\left(S_{0}-S_{s s}\right)}{V_{L}}-\frac{\mu X_{s s}}{Y_{x / s}}-\frac{\left(\alpha_{S A} \mu X_{s s}+\beta_{S A} X_{s s}\right)}{Y_{S A / s}} \\
& -\frac{\left(\alpha_{A A} \mu X_{s s}+\beta_{A A} X_{s s}\right)}{Y_{A A / s}}-\frac{\left(\alpha_{L A} \mu X_{s s}+\beta_{L A} X_{s s}\right)}{Y_{L A / s}}-\frac{\left(\alpha_{F A} \mu X_{s s}+\beta_{F A} X_{s s}\right)}{Y_{F A / s}}-m_{s} X_{s s}
\end{aligned}
$$

where $S_{0}$ is initial glucose substrate feed concentration $\left(\mathrm{kg} / \mathrm{m}^{3}\right), \mathrm{m}_{\mathrm{s}}$ is glucose substrate maintenance term $(\mathrm{kg} / \mathrm{kg}), Y_{x / s}$ is yield coefficient of biomass from glucose substrate $(\mathrm{kg} / \mathrm{kg}), Y_{S A / s} Y_{A A / s} Y_{L A / s} Y_{F A / s}$ are yield coefficients for succinic acid, acetic acid, lactic acid, and formic acid, respectively, from glucose substrate $(\mathrm{kg} / \mathrm{kg})$. The steady-state cell biomass balance by substitution became:

$$
\mu=\frac{F}{V_{L}}=D
$$

Where $D$ is dilution rate $\left(\mathrm{s}^{-1}\right)$. Substituting this dilution rate into steady-state mass balances resulted in the following:

$$
\begin{aligned}
& S_{s s}=\frac{D K_{s}}{\mu_{m}-D} \\
& X_{s s}=\frac{\left(D \left(\left(\frac{1}{Y_{x / s}}\right)+\left(\frac{\alpha_{s A}}{Y_{S A s s}}\right)+\left(\frac{\alpha_{A A}}{Y_{A A s}}\right)+\right.\right.}{(V)} \\
& P_{S A s s}=\alpha_{S A} X_{s s}+\frac{\beta_{S A} X_{s s}}{D} \\
& P_{A A s s}=\alpha_{A A} X_{s s}+\frac{\beta_{A A} X_{s s}}{D}
\end{aligned}
$$$$
X_{s s}=\frac{\mu_{m}-D}{\left(D\left(\left(\frac{1}{Y_{x / s}}\right)+\left(\frac{\alpha_{S A}}{Y_{S A / s}}\right)+\left(\frac{\alpha_{A A}}{Y_{A A / s}}\right)+\left(\frac{\alpha_{L A}}{Y_{L A / s}}\right)+\left(\frac{\alpha_{F A}}{Y_{F A / s}}\right)+\left(\frac{\beta_{S A}}{Y_{S A / s}}\right)+\left(\frac{\beta_{A A}}{Y_{A A / s}}\right)+\left(\frac{\beta_{L A}}{Y_{L A / s}}\right)+\left(\frac{\beta_{F A}}{Y_{F A / s}}\right)+m_{s}\right)\right.}
$$ 


$$
\begin{aligned}
& P_{L A s s}=\alpha_{L A} X_{s s}+\frac{\beta_{L A} X_{s s}}{D} \\
& P_{F A s s}=\alpha_{F A} X_{s s}+\frac{\beta_{F A} X_{s s}}{D}
\end{aligned}
$$

An additional steady-state equation for volumetric succinic acid productivity was included:

$$
D P_{S A s s}=\alpha_{S A} D X_{s s}+\frac{\beta_{S A} X_{s s}}{D}
$$

The steady-states of Equation 14-20 were then plotted against dilution rate. Graphically determined optimal dilution rate corresponding to maximum steady-state volumetric productivity was used to obtain the steady-state outlet liquid-phase biomass, glucose, and carboxylic acid product concentrations. Optimal dilution rate was also obtainable by setting the derivative of steady-state volumetric productivity with respect to dilution rate to 0 . The fermentor liquid volume specifying dimensions for the baseline process as well as the CFD simulation was the ratio of $\mathrm{F}$ to optimal dilution rate. A 3:1 liquid fermentor height to diameter ratio was then assumed:

$$
D_{T}=\left(\frac{4 V_{L}}{3 \pi}\right)^{1 / 3}
$$

where $D_{T}$ is fermentor diameter $(\mathrm{m})$. Single-phase flow for Newtonian fluid, a three-impeller, 6-blade Rushton-turbine agitator, and a uniform inter-impeller axial spacing and distance from the bottom [46] equal to impeller diameter which itself was a third of fermentor diameter were assumed for both the baseline process and CFD simulation. For the baseline process, $40^{\circ} \mathrm{C}$ inlet temperature and $200 \mathrm{rpm}$ agitation speed was assumed. CFD was used to simulate the effect of inlet temperature at $40^{\circ} \mathrm{C}$ and $42^{\circ} \mathrm{C}$ and impeller speeds at a minimal value, 100rpm, and 200rpm on cooling jacket area. Minimal impeller speed was estimated as follows [34]:

$$
N_{0}=\left(1.22+1.25\left(\frac{D_{T}}{D_{\text {impeller }}}\right)\right)\left(\frac{\sigma g}{\rho_{f}}\right)^{1 / 4}
$$

where $\mathrm{N}_{0}$ is minimum impeller speed (rps), $\sigma$ is surface tension of fermentation broth (dyne $/ \mathrm{m})$ and $\rho_{f}$ is fermentation broth density $(\mathrm{kg} /$ $\left.\mathrm{m}^{3}\right)$.

In addition to this simulation, the CFD flow fields resulting from a smaller fermentor liquid volume and alternate impeller spacing [47] were visualized. For this the bottom, middle, and top impeller distance from the fermentor bottom were instead multiples of $0.166,1.2$, and 1.967 times the fermentor diameter. The multiple reference frame (MRF) model was applied until the flow fields in the stirred-tank fermentor converged to steady-state values. MRF involved a steady-state approach in which individual cell zones moved at different rotational speeds. The flow fields for zones with impellers were solved with MRF equations, whereas those with no moving parts were solved using stationary-frame equations. The CFD governing equations were provided in the FLUENT (v.6.3.26) documentation [36]. Among these were the continuity equations, momentum equations, and turbulence model equations used to calculate the fluctuations involving momentum. To predict the effects of inlet temperature and impeller speed, non-aerated agitator power consumption was calculated by CFD as follows:

$$
P_{\text {impeller } 0}=2 \pi N_{\text {impeller }} M
$$

where $P_{\text {impeller } 0}$ is non-aerated impeller power consumption (W), and $M$ is torque (moment) on the axis due to the impeller $(\mathrm{N} \bullet \mathrm{m})$. Alternatively, a dimensionless power number $N_{p}$ could be determined graphically from a Reynold's Number to estimate non-aerated power consumption as follows: [44]

$$
\operatorname{Re}_{p}=\frac{N_{\text {impeller }} D_{\text {impeller }}^{2} \rho_{f}}{\mu_{f}}
$$

where $\mu_{f}$ is fermentation broth dynamic viscosity and [44]

$$
P_{\text {impeller } 0}=N_{p} \rho_{f} N_{\text {impeller }}^{3} D_{\text {impeller }}^{5}
$$

The Finite Volume Method (FVM) was the CFD numerical solution technique used since it accommodated unstructured meshes and was based on fundamental laws of conservation [48]. The continuity and momentum equations were discretized into algebraic equations and then solved numerically. The SIMPLE algorithm was used to solve velocity-pressure coupled differential equations. No-slip boundary conditions were applied on all walls. The wall temperature was set at the fermentation broth temperature $39^{\circ} \mathrm{C}$ [6]. The convergence criteria required that the scaled residuals decrease to $10^{-5}$ for each conservative equation. For gas-liquid two-phase flow where $\operatorname{Re}>10,000$, mixing time (s) was estimated as follows [44]:

$$
t_{m}=\frac{6\left(\frac{D_{T}}{D_{\text {impeller }}}\right)^{3}}{N_{\text {impeller }} N_{p}^{0.33}}
$$

Aerated power consumption $P_{\text {impellerg }}$ was then calculated [44]:

$$
\frac{P_{\text {impeller } g}}{P_{\text {impeller } 0}}=0.10\left(\frac{F_{g}}{N_{\text {impeller }} V_{L}}\right)^{-0.25}\left(\frac{N_{\text {impeller }}^{2} D_{\text {impeller }}}{g H_{\text {impeller }} V_{L}^{2 / 3}}\right)^{-0.20}
$$

where $F_{g}$ is volumetric $\mathrm{CO}_{2}$ gas flow rate $\left(\mathrm{m}^{3} / \mathrm{s}\right)$, g is gravitational constant $\left(\mathrm{m}^{2} / \mathrm{s}\right)$, and $H_{\text {impeller }}$ is height of impeller blade $(\mathrm{m})$. The rate $F_{g}$ was obtained from $V_{L}$ and the $0.25 \mathrm{vvm}$ of pure $\mathrm{CO}_{2}$ reportedly sparged in M. succiniciproducens MBEL55E fermentation [6]. A superficial $\mathrm{CO}_{2}$ gas velocity $v_{g}(\mathrm{~m} / \mathrm{s})$ was obtained from $F_{g}$ and $D_{T}$, and a volumetric gas-liquid mass transfer coefficient $k_{L} a\left(\mathrm{~s}^{-1}\right)$ was calculated from an empirical correlation for non-coalescing (dirty) dispersions as follows [34]:

$$
k_{L} a=0.002\left(\frac{P_{\text {impeller } g}}{V_{L}}\right)^{0.7} v_{g}^{0.2}
$$

Using the CFD-derived $\mathrm{k}_{\mathrm{L}} \mathrm{a}$, the steady-state $\mathrm{CO}_{2}$ liquid-phase concentration exiting the fermentor $\left[\mathrm{CO}_{2 L}\right],\left(\mathrm{kg} / \mathrm{m}^{3}\right)$ was then solved from the following steady-state mass balance:

\section{$\mathrm{CO}_{2}$ liquid-phase mass balance:}

$$
\frac{d V_{L}\left[\mathrm{CO}_{2 L}\right]_{s s}}{d t}=0=F_{L}\left(\left[\mathrm{CO}_{2 L}\right]_{b}-\left[\mathrm{CO}_{2 L}\right]_{s s}\right)+K_{g} a V_{L} P\left(y-\frac{H\left[\mathrm{CO}_{2 L}\right]_{s s}}{P}\right)-r_{c 0_{2}} V_{L}
$$

where $\left.\mathrm{CO}_{2}\right]$ is inlet $\mathrm{CO}_{2}$ concentration $\left(\mathrm{kg} / \mathrm{m}^{3}\right)$, y is $\mathrm{CO}_{2}$ mass fraction in inlet gas sparging stream, $\mathrm{H}$ is Henry's Law constant $\left(\mathrm{Pa} \mathrm{kg} \mathrm{CO} \mathrm{m}^{-3}\right)$, $\mathrm{P}$ is total pressure $(\mathrm{Pa}), r_{c 0_{2}}$ is volumetric rate of consumption of $\mathrm{CO}_{2}$ by reaction in the liquid phase $(\mathrm{kg} / \mathrm{s})$, and $K_{g} a$ is overall gas phase mass transfer coefficient $\left(\mathrm{kgPa}^{-1} \mathrm{~s}^{-1}\right)$. The Kga was approximated with $\mathrm{k}_{\mathrm{g}}$ a assumed negligible:

$$
\frac{1}{K_{g} a}=\frac{1}{k_{g} a}+\frac{H}{k_{L} a}
$$

It was assumed that there was no axial or time-dependence on the gas phase composition of the bubble since pure $\mathrm{CO}_{2}$ was assumed sparged and $y=1$. Total pressure accounted for atmospheric and fermentor height-dependent hydrostatic pressure. $\mathrm{CO}_{2}$ is incorporated in the PEP carboxylation pathway [32], and a reported 1:1 ratio of moles of $\mathrm{CO}_{2}$ fixed to moles of succininc acid produced [6] was used for calculation of $r_{\mathrm{co}_{2}}$. Metabolic production of $\mathrm{CO}_{2}$ by M. succiniciproducens was not modeled [6]. The Henry's Law constant was adjusted for ionic 
strength of fermentation broth using Bunsen coefficients [32]. The inlet liquid-phase concentration $\left[\mathrm{CO}_{2}\right]$, was $0 \mathrm{~kg} / \mathrm{m}^{3}$.

Flow rates and solved $\left[\mathrm{CO}_{2 L}\right]_{s}$ concentration and inlet gas-phase concentration $\left[\mathrm{CO}_{2 G}\right]$, were then used to calculate steady-state gasphase $\mathrm{CO}_{2}$ concentration $\left[\mathrm{CO}_{2 G}\right]_{\mathrm{ss}}$ exiting the fermentor at the top $(\mathrm{kg} /$ $\mathrm{m}^{3}$ ) from a total $\mathrm{CO}_{2}$ fermentor mass balance. The mass fraction of water vapor also exiting the top was estimated from ratio of water vapor pressure estimated with the Antoine equation [49] at atmospheric pressure and $39^{\circ} \mathrm{C}$ to total atmospheric pressure. This and the exiting $\mathrm{CO}_{2}$ gas mass flow rate $F_{\mathrm{CO} 2 \mathrm{~g}-\text { out }}(\mathrm{kg} / \mathrm{s})$ were then used to obtain a mass flow rate of exiting water vapor $F_{\text {watervapor }}(\mathrm{kg} / \mathrm{s})$. With gas and liquid-phase mass flow rates now specified, a fermentor energy balance provided the heat removed term using the agitator power consumption and exiting $\mathrm{CO}_{2}$ and water vapor enthalpy terms obtained from CFD simulation:

$$
Q_{\text {removed }}=\eta_{\text {impeller }} P_{\text {impellerg }}+\sum_{i=1}^{n} F_{i_{\text {in }}} H_{i_{\text {in }}}-\sum_{i=1}^{n} F_{i_{\text {out }}} H_{i_{\text {out }}}
$$

where $Q_{\text {removed }}$ is rate of heat to be removed (J/s), $\eta_{\text {impeller }}$ is gearbox efficiency, $F_{i_{i, u}}$ and $F_{i_{o u t}}$ are inlet and outlet mass flow rates of components i, respectively $(\mathrm{kg} / \mathrm{s}), H_{i_{\text {in }}}$ and $H_{i_{\text {out }}}$ are inlet and outlet mass enthalpy of components $\mathrm{i}$, respectively $(\mathrm{J} / \mathrm{kg})$. With exception of terms for water vapor involving a phase change and M. succiniciproducens cells, component enthalpy terms were calculated as follows:

$$
H_{i}=H_{i}^{o}\left(T_{R}\right)+\int_{T_{R}}^{T_{2}} C_{p_{i}} d T
$$

where $H_{i}^{o}\left(T_{R}\right)$ is heat of combustion for component $\mathrm{i}(\mathrm{J} / \mathrm{kg})$ at reference temperature $T_{R}=25^{\circ} \mathrm{C}, T_{2}$ is fermentation broth temperature of $39^{\circ} \mathrm{C}$ for outlet streams and either the baseline $40^{\circ} \mathrm{C}$ or simulated $42^{\circ} \mathrm{C}$ for inlet liquid streams, and $C_{p_{i}}$ is heat capacity of component $\mathrm{i}(\mathrm{J} / \mathrm{kg}-\mathrm{C})$. Water vapor mass enthalpy was similarly calculated but by also adding an enthothermic enthalpy of vaporization for water vapor $(\mathrm{J} / \mathrm{kg})$. Heat of combustion mass enthalpy for M. succiniciproducens cell biomass on dry-weight, $8 \%$ ash-basis was calculated by the Dulong equation [34]:

$$
H_{\text {cell }}^{o}=8.076 \mathrm{C}+34.462\left(H-\frac{O}{8}\right)
$$

where $\mathrm{C}, \mathrm{H}$, and $\mathrm{O}$ represent the experimentally-determined weight fractions of carbon, hydrogen, and oxygen, respectively, for $M$. succiniciproducens from its cell elemental composition $\mathrm{CH}_{1.736} \mathrm{O}_{0.367} \mathrm{~N}_{0.240}$ [6]. Assuming cooling water with inlet and outlet temperatures of $25^{\circ} \mathrm{C}$ and $35^{\circ} \mathrm{C}$ flowing through an external jacket having a small equivalent width of $0.0254 \mathrm{~m}$, a high cooling water mass flow rate was obtained from $Q_{\text {removed }}$, temperature difference, and water heat capacity. Fermentor cooling jacket heat transfer area requirement was therefore calculated:

$$
A_{\text {heat }}=\frac{Q_{\text {removed }}}{U\left(T_{C}-T_{F}\right)}
$$

where $U$ is overall heat transfer coefficient $\left(\mathrm{W} / \mathrm{m}^{2}-\mathrm{C}\right), \mathrm{T}_{\mathrm{C}}$ is average cooling water temperature of $30^{\circ} \mathrm{C}$, and $\mathrm{T}_{\mathrm{F}}$ is fermentation broth temperature of $39^{\circ} \mathrm{C}$. Like the previous overall mass transfer coefficient $\mathrm{K}_{\mathrm{g}} \mathrm{a}$, overall heat transfer coefficient was approximated as a sum of resistances in series as follows:

$$
\frac{1}{U}=\frac{1}{h_{F}}+\frac{1}{h_{F D}}+\frac{\Delta x}{k_{W}}+\frac{1}{h_{C}}+\frac{1}{h_{C D}}
$$

where $h_{F}$ is heat transfer coefficient for the fermentation broth (W/ $\left.\mathrm{m}^{2}-\mathrm{C}\right), h_{F D}$ is heat transfer coefficient (a.k.a. dirt factor) from fermentation broth fouling deposits $\left(\mathrm{W} / \mathrm{m}^{2}-\mathrm{C}\right), \mathrm{k}_{\mathrm{w}}$ is thermal conductivity of the fermentor wall stainless steel $\left(\mathrm{J} / \mathrm{m}^{2}\right), \Delta \mathrm{x}$ is fermentor wall thickness $(\mathrm{m})$, $\mathrm{h}_{\mathrm{c}}$ is cooling water heat transfer coefficient $\left(\mathrm{W} / \mathrm{m}^{2}-\mathrm{C}\right)$, and $h_{C D}$ is cool- ing water fouling deposits heat transfer coefficient $\left(\mathrm{W} / \mathrm{m}^{2}-\mathrm{C}\right)$. The fermentation broth heat transfer coefficient $\mathrm{h}_{\mathrm{F}}$ depended directly on impeller speed and diameter specified for CFD simulation as follows [34]:

$$
\frac{h_{F} D_{T}}{k_{F}}=0.42\left(\frac{D_{\text {impeller }}^{2} N_{\text {impeller }} \rho_{F}}{\mu_{F}}\right)^{0.66}\left(\frac{C_{p F} \mu_{F}}{k_{F}}\right)^{0.33}\left(\frac{\mu_{F}}{\mu_{W}}\right)^{0.14}
$$

where $\mu_{W}$ is wall viscosity $(\mathrm{kg} / \mathrm{s}-\mathrm{m})$ and $k_{F}$ is fermentation broth thermal conductivity $(\mathrm{W} / \mathrm{m}-\mathrm{C})$. Effect of impeller speed and inlet temperature on heat transfer area was therefore simulated.

\section{Cell microfiltration}

A two-stage cross-flow tubular microfiltration unit, whereby the retentate of the first stage became the feed of the second stage, then removed and recovered all cells from the broth exiting the fermentor containing succinate, acetate, formate, lactate, and unconsumed glucose. The intended recycle of cells back to the fermentor for simplicity was not simulated. Final cell retentate concentration was limited to 100 $\mathrm{kg} / \mathrm{m} 3$ because this corresponded to an exponential increase in viscosity and a non-Newtonian transition of a lactic acid fermentation broth increasing pump energy consumption [50]. For the mass balance, the permeate volumetric flow rate of the first stage was equal to that of the second stage, and inter-stage recycle ratio was equal to 1 . All non-cell components in the feed transferred to the permeate because they were below the molecular weight cutoff of the microfiltration membrane. Recirculation rate was $6 \mathrm{~m} / \mathrm{s}$. Steady-state permeate flux was estimated using a gel polarization model $[51,52]$ :

$$
J_{\text {micro-2 }}=1.31\left(\frac{D_{\text {cell }}^{2} \gamma}{L_{\text {micro-2 }}}\right)^{1 / 3}\left(\frac{c_{\text {gcell }}}{c_{\text {0 cell }}}-1\right)^{1 / 3}
$$

where $\mathrm{D}_{\text {cell }}$ is particle diffusion coefficient of M. succiniciproducens cells in succinic acid fermentation broth $\left(\mathrm{m}^{2} / \mathrm{s}\right), \mathrm{L}_{\text {micro-2 }}$ is tube length $(\mathrm{m}), \gamma$ is shear rate $\left(\mathrm{s}^{-1}\right), \mathrm{C}_{\text {geell }}$ is gel polarization volume fraction, and $\mathrm{C}_{\text {ocell }}$ is bulk cell volume fraction. Effect of single-stage on area and power requirements, calculated as before, was simulated and compared to twostage baseline process.

\section{Adsorption and desorption}

A granulated activated carbon (GAC) counter-current moving-bed adsorber then removed $98 \%$ of glucose from microfiltration permeate to further purify the products. Intended recycle of glucose back to the fermentor for simplicity was not simulated. Only $2.5 \%$ lactate and $1 \%$ succinate was lost in the sorption process. GAC sorbent was selected for its low cost and future derivation from biochar via pyrolysis of recovered lignin. Column height was estimated from the product of NTU (Number of Transfer Units) and HTU (Height of Transfer Units).NTU was calculated by integrating area from a plot of the single-component glucose equilibrium curve and of the mass balance-derived operating line [53]. The adsorption equilibrium curve was generated from Langmuir single-component glucose-GAC equilibria isotherm data [54]:

$$
q_{g l u}=\frac{q_{m_{g l u}} b C_{g l u}}{1+b C_{g l u}}
$$

where $\mathrm{q}_{\mathrm{glu}}$ is glucose concentration in GAC sorbent phase (mol glucose/ $\mathrm{kg}$ GAC sorbent), $\mathrm{q}_{\mathrm{m}}$ is maximum sorbent capacity (mol glucose $/ \mathrm{kg}$ GAC sorbent), $\mathrm{C}_{\text {glu }}$ is glucose concentration in liquid phase (mol glucose $/ \mathrm{m}^{3}$ feed solution). HTU was estimated as follows [53]:

$$
H T U=\frac{v_{\text {adsorber }}}{K_{\text {adsorber }} a_{i}}
$$

where $K_{\text {adsorber }}$ is overall mass transfer coefficient $(\mathrm{m} / \mathrm{s}), \mathrm{v}_{\text {adsorber }}$ is in dustry-acceptable adsorber hydraulic loading rate based on selected 
column diameter $(\mathrm{m} / \mathrm{s})$, and $\mathrm{a}_{\mathrm{i}}$ is particle interfacial area/volume ratio $\left(\mathrm{m}^{-1}\right)$ calculated as follows:

$$
a_{i}=\frac{6(1-\varepsilon)}{d_{p}}
$$

where $\varepsilon$ is bed porosity or void fraction (dimensionless) and $\mathrm{d}_{\mathrm{p}}$ is GAC particle diameter $(\mathrm{m})$, which for the baseline process was $800 \mu \mathrm{m}$ but was also simulated at $600 \mu \mathrm{m}$. Overall mass transfer coefficient $\mathrm{K}$ was estimated as follows [55]:

$$
\frac{1}{K_{\text {adsorber }}}=\frac{1}{k_{\text {film }}}+\frac{1}{q_{m} k_{s}}
$$

where $\mathrm{k}_{\text {film }}$ is film-mass transfer coefficient $(\mathrm{m} / \mathrm{s})$ and $\mathrm{k}_{\mathrm{s}}$ is intra-particle mass transfer coefficient $(\mathrm{m} / \mathrm{s})$. The $\mathrm{k}_{\mathrm{flm}}$ and $\mathrm{k}_{\mathrm{s}}$ and associated effective and Knudsen diffusivities were estimated from empirical correlations[55]. Adsorber column pressure drop for pump power consumption was estimated with the Ergun equation [56]. For a desorber column, it was assumed that regenerant had $0 \%$ glucose entering. A $96 \%$ regeneration yield in the desorber was assumed using $90^{\circ} \mathrm{C}$ hot water with $4 \% \mathrm{NaOH}, 0.3 \%$ oxidant, and $0.1 \%$ surfactant [57]. Regeneration flow rate was assumed $25 \%$ greater than adsorber feed flow rate.

\section{Nanofiltration}

A single-stage cross-flow hollow-fiber nanofiltration unit then separated the succinate from all formate, acetate, and most lactate by exploiting both the unique divalent (2-) charge of succinate and its molecular weight and size [17]. Succinate rejection in quarternary solutions containing monovalent formate, lactate, and acetate anions was shown to be much higher than that in single-salt solution because of their facilitated transport due to Donnan effect in the presence of divalent succinate anion [17]. For the mass balance, at maximum permeate flux, the rejection coefficients were $95 \%, 38 \%, 0.01 \%$, and $-60 \%$ for succinate, lactate, acetate, and formate, respectively [17]. The quaternary mixture of $0.3 \mathrm{M}$ succinate, $0.1 \mathrm{M}$ acetate, $0.1 \mathrm{M}$ lactate, and $0.1 \mathrm{M}$ formate salts that corresponded to these rejection coefficients using an NF45 membrane was formulated to simulate an actual fermention medium[17]. These published values were deemed applicable for our model because the feed mixture's $0.3 \mathrm{M}$ succinate concentration [17] was similar to the $0.284 \mathrm{M}$ succinate concentration from our process mass balance. Similarly high succinate rejection coefficients of $97 \%, 95 \%$, and $84 \%$ at 400,300 , and 200 psig trans-membrane pressures, respectively, were also previously obtained in another work and suggested that succinate rejection became increasingly less dependent on transmembrane pressure as transmembrane pressure increased [26]. Hollow-fiber modules were selected over plate-frame module because particulate plugging was a low risk. Operating conditions for recirculation flow rate, trans-membrane pressure, number and length of hollow fibers were from literature $[17,58]$. Retentate bulk and gel polarization concentrations depended on succinate having highest molecular weight and concentration of all salts. Steady-state permeate flux was estimated via a gel polarization model for dissolved solutes [58]:

$$
J_{\text {nano }}=k_{\text {nano }} \ln \frac{C_{g s u c}}{C_{0 s u c}}
$$

where $\mathrm{k}_{\text {nano }}$ is succinate mass transfer coefficient $(\mathrm{m} / \mathrm{s}), \mathrm{C}_{\mathrm{g} \text {-suc }}$ is gel polarization concentration $\left(\mathrm{kg} / \mathrm{m}^{3}\right)$, and $\mathrm{C}_{\text {o-suc }}$ is bulk feed concentration of succinate $\left(\mathrm{kg} / \mathrm{m}^{3}\right)$. The $\mathrm{C}_{\mathrm{g} \text {-suc }}$ was obtained by first plotting steady-state permeate flux as a function of trans-membrane pressure for reported succinate concentrations [17]. Natural logarithm of sodium succinate concentration was then plotted against these fluxes to yield a straight line equation where the $\mathrm{x}$-intercept corresponding to $\mathrm{J}_{\text {nano }}=0$ at $\mathrm{C}_{\mathrm{g}} / \mathrm{C}_{\mathrm{o}}$ $=1$ represented the $\mathrm{C}_{\mathrm{g} \text {-suc }}$ of interest. The $\mathrm{k}_{\mathrm{mt}}$ was determined from $\mathrm{j}_{\mathrm{D}}$ - factor correlation for hollow fibers and turbulent flow regime [58]. Area and power requirement was calculated as before.

\section{Ion exchange}

Nanofiltration retentate then entered one of two fixed-bed ion exchanger columns containing weak anion exchange Dowex resin to both acidify and purify the undisassociated (protonated) succinic acid from lactic acid via its greater hydrophobicity and unique divalent charge [31]. Column loading of the binary lactate and succinate mixture occurred at $\mathrm{pH}=4$ above the $\mathrm{pKa}$ of lactic acid and below the $\mathrm{pKal}$ of succinic acid [31]. While one column was loaded, a second was regenerated with three bed volumes of $90^{\circ} \mathrm{C}$ water [59]. Loading and regeneration times were equal for steady-state operation. Sorption temperature exceeded $55^{\circ} \mathrm{C}$ to prevent crystallization of the highly concentrated succinic acid, although its adsorption efficiency on Amberlite resin is reportedly reduced at higher temperatures [60]. Ion exchange column height was the sum of SBH (Stochiometric Bed Height)[61] and LUB (Length of Unused Bed) [40]:

$$
L U B=\left(1-\frac{t_{b}}{t^{*}}\right) L_{1}
$$

where $L_{1}$ is length of small-scale column $(m), t_{b}$ is breakthrough time for succinic acid (s), $t^{*}$ is midpoint time for succinic acid (s). $t_{b}$ and $t^{*}$ were estimated from the breakthough curves of lactic and succinic acids on Dowex resin column [31], and:

$$
S B H=\frac{v_{\text {ion }} t_{s}}{(1-\varepsilon)\left(\frac{q_{0}}{c_{0}}\right)}
$$

where $\mathrm{v}_{\mathrm{ion}}$ is industry-acceptable ion-exchanger hydraulic loading rate based on selected column diameter $(\mathrm{m} / \mathrm{s}), \mathrm{q}_{\mathrm{o}} / \mathrm{c}_{\mathrm{o}}$ is ratio of feed succinate liquid-phase concentration to Dowex sorbent succinate solid phaseconcentration in equilibrium, and $t_{s}$ is service time(s). A service time of 3600 seconds corresponded to 15 column-bed loading volumes when column regeneration initiated [31]. To derive $\mathrm{q}_{\mathrm{o}} / \mathrm{c}_{\mathrm{o}}$, a multi-component equilibria Langmuir model and constants accounting for 1-1 and 1-2 binding were used to generate equilibrium curves [31].

\section{Crystallization}

Ion exchanger eluant then entered an idealized continuous, circulating magma, stirred-tank, cooling-type MSMPR (Mixed Solution Mixed Product Removal) crystallizer to supersaturate only anhydrous 2- succinic acid from solution at $\mathrm{pH}=2$ and $4^{\circ} \mathrm{C}$ [16]. Yield was obtained [62]:

$$
Y_{c r y}=S_{o w} R_{h}\left[C_{0 s u c-c r y}-C_{F s u c-c r y}\left(1+V_{d}-V_{e}\right)\right]
$$

where $\mathrm{Y}_{\text {cry }}$ is maximum yield rate of crystal produced $(\mathrm{kg} / \mathrm{s}), \mathrm{S}_{0 \mathrm{w}}$ is weight of original free solvent water $(\mathrm{kg} / \mathrm{s}), \mathrm{V}_{\mathrm{d}}$ is added diluent $(\mathrm{kg} / \mathrm{kg}$ original free solvent water), $\mathrm{V}_{\mathrm{e}}$ is solvent loss from evaporation $(\mathrm{kg} / \mathrm{kg}$ original free solvent water), $\mathrm{C}_{\text {osuc-cry }}$ is initial concentration of succinic acid crystal in feed ( $\mathrm{kg}$ anhydrous succinic acid/ $\mathrm{kg}$ free solvent water), $\mathrm{C}_{\mathrm{Fsuc}-\mathrm{cry}}$ is final concentration assumed to be solubility at $4^{\circ} \mathrm{C}$ and $\mathrm{pH}=2$ of succinic acid crystal in saturated mother liquor (kg anhydrous succinic acid/kg free solvent water), and $\mathrm{R}_{\mathrm{h}}$ is ratio of molecular weights of hydrate and anhydrous salts. About $2 \%$ of the water in the feed was assumed evaporated. Crystal growth was size-dependent, and nucleation was mediated by both primary and secondary mechanisms from crystal-crystallizer impeller or wall collisions [63]. To estimate crystallizer volume, experimentally-derived batch kinetic expressions for succinic acid nucleation and growth rates as functions of supersaturations were available in literature [30]: 
Citation: Wensel P, Yu L, Chen S (2011) Simulation with Computational Fluid Dynamics of Succinic Acid and Co-Product Biorefinery Process. J Bioprocess Biotechniq S2:002 doi:10.4172/2155-9821.S2-002

Page 9 of 17

$$
\begin{aligned}
& B=k_{B} \Delta c^{b} M_{T}^{v} N_{c r y-i m p e l l e r}^{z} \\
& G=k_{g} \Delta c^{s} N_{c r y-i m p e l l e r}^{p}
\end{aligned}
$$

However, we combined these into a more useful relative-kinetic expression:

$$
B=k_{n} N_{c r y-i m p e l l e r}^{h} G^{g} M_{T}^{j}
$$

where $B$ is crystal nucleation rate $\left(\mathrm{s}^{-1}\right), \mathrm{G}$ is crystal growth rate $\left(\mathrm{s}^{-1}\right), \mathrm{N}$ is impeller speed (rps), $\mathrm{M}_{\mathrm{T}}$ is magma density ( $\mathrm{kg}$ succinic acid crystal $/ \mathrm{m}^{3}$ mother liquor), and $\mathrm{k}_{\mathrm{n}}, \mathrm{k}_{\mathrm{g}} \mathrm{k}_{\mathrm{B}}, \mathrm{h}, \mathrm{s}, \mathrm{j}, \mathrm{b}, \mathrm{v}, \mathrm{z}$ are dimensionless coefficients and exponents Assuming a power-volume ratio $\varepsilon$ proportional to impeller speed as $\varepsilon=\mathrm{P} / \mathrm{V} \sim \mathrm{N}^{3}$, by substitution crystallizer residence time was then estimated [63]:

\begin{tabular}{|c|c|c|c|c|c|c|c|}
\hline $\begin{array}{c}\text { Corn Stover Feed } \\
\text { Handling }\end{array}$ & Values & Pre-Hydrolysis & Values & Blow-Down Tank & Values & $\begin{array}{c}\text { Liquid-Solid Sepa- } \\
\text { ration }\end{array}$ & Values \\
\hline Temperature $\left({ }^{\circ} \mathrm{C}\right)$ & 40 & Temperature $\left({ }^{\circ} \mathrm{C}\right)$ & 245 & Temperature $\left({ }^{\circ} \mathrm{C}\right)$ & 101 & Temperature $\left({ }^{\circ} \mathrm{C}\right)$ & 70 \\
\hline Pressure (atm) & 1 & Pressure (atm) & 13.6 & Pressure (atm) & 1 & Pressure (atm) & 1 \\
\hline Stream ID & Flow rate $(\mathrm{kg} / \mathrm{hr})$ & Stream ID & Flow rate $(\mathrm{kg} / \mathrm{hr})$ & Stream ID & Flow rate $(\mathrm{kg} / \mathrm{hr})$ & Stream ID & Flow rate $(\mathrm{kg} / \mathrm{hr})$ \\
\hline 1 & 88542 & 5 & 137565 & 8 & 295139 & 10 & 256479 \\
\hline 2 & 15625 & 6 & 3250 & 9 & 38660 & 11 & 148758 \\
\hline 3 & 12042 & 7 & 154324 & & & 12 & 312095 \\
\hline 4 & 45440 & & & & & & \\
\hline Slurring Tank & Values & Sacharification & Values & Lignin Microfiltration & Values & Centrifugation & Values \\
\hline Temperature $\left({ }^{\circ} \mathrm{C}\right)$ & 65 & Temperature $\left({ }^{\circ} \mathrm{C}\right)$ & 65 & Temperature $\left({ }^{\circ} \mathrm{C}\right)$ & 65 & Temperature $\left({ }^{\circ} \mathrm{C}\right)$ & 65 \\
\hline Pressure (atm) & 1 & Pressure (atm) & 1 & Pressure (atm) & 1.48 & Pressure (atm) & 1 \\
\hline Stream ID & Flow rate $(\mathrm{kg} / \mathrm{hr})$ & Stream ID & Flow rate $(\mathrm{kg} / \mathrm{hr})$ & Stream ID & Flow rate $(\mathrm{kg} / \mathrm{hr})$ & Stream ID & Flow rate $(\mathrm{kg} / \mathrm{hr})$ \\
\hline 13 & 93142 & 16 & 262335 & 17 & 262335 & 18 & 78004 \\
\hline 14 & 564 & & & & & 19 & 37694 \\
\hline 15 & 168628 & & & & & & \\
\hline Fermentation & Values & $\begin{array}{l}\text { Cell Microfiltration } \\
\text { Stage\#1 }\end{array}$ & Values & $\begin{array}{l}\text { Cell Microfiltration } \\
\text { Stage\#2 }\end{array}$ & Values & $\begin{array}{l}\text { Adsorption and } \\
\text { Desorption }\end{array}$ & Values \\
\hline Temperature $\left({ }^{\circ} \mathrm{C}\right)$ & 39 & Temperature $\left({ }^{\circ} \mathrm{C}\right)$ & 39 & Temperature $\left({ }^{\circ} \mathrm{C}\right)$ & 39 & Temperature $\left({ }^{\circ} \mathrm{C}\right)$ & 68 \\
\hline Pressure (atm) & 1 & Pressure (atm) & 1.97 & Pressure (atm) & 1.97 & Pressure (atm) & 1 \\
\hline Stream ID & Flow rate $(\mathrm{kg} / \mathrm{hr})$ & Stream ID & Flow rate $(\mathrm{kg} / \mathrm{hr})$ & Stream ID & Flow rate $(\mathrm{kg} / \mathrm{hr})$ & Stream ID & Flow rate $(\mathrm{kg} / \mathrm{hr})$ \\
\hline 20 & 40310 & 23 & 224641 & 25 & 144952.5 & 28 & 159377 \\
\hline 21 & 184331 & 24 & 79688.5 & 26 & 79688.5 & 29 & 199287 \\
\hline 22 & 224641 & & & 27 & 65264 & 30 & 199221 \\
\hline Nanofiltration & Values & $\begin{array}{l}\text { 2-Column lon } \\
\text { Exchange }\end{array}$ & Values & Crystallization & Values & & \\
\hline Temperature $\left({ }^{\circ} \mathrm{C}\right)$ & 25 & Temperature $\left({ }^{\circ} \mathrm{C}\right)$ & 73 & Temperature $\left({ }^{\circ} \mathrm{C}\right)$ & 4 & & \\
\hline Pressure (atm) & 20.41 & Pressure (atm) & 1 & Pressure (atm) & 1 & & \\
\hline Stream ID & Flow rate $(\mathrm{kg} / \mathrm{hr})$ & Stream ID & Flow rate $(\mathrm{kg} / \mathrm{hr})$ & Stream ID & Flow rate (kg/hr) & & \\
\hline 31 & 159310 & 34 & 51424.2 & 37 & 795 & & \\
\hline 32 & 99569 & 35 & 59741.3 & 38 & 39168 & & \\
\hline 33 & 59741 & 36 & 51424.2 & 39 & 11461 & & \\
\hline
\end{tabular}

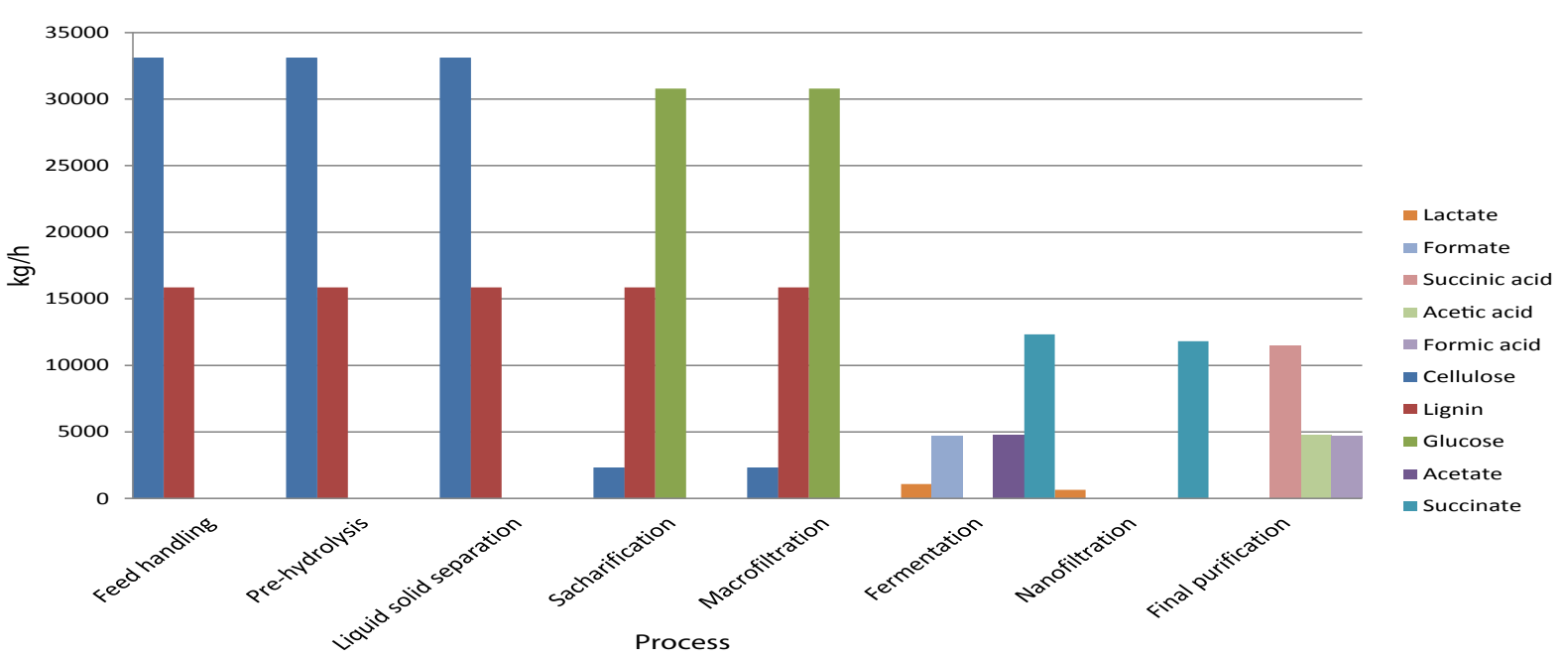

Figure 3: Changes in major stream flow rates throughout process.

Table 3: Major processes and associated flow rates, temperatures, and pressures. 


$$
L_{m}=3.67\left[\frac{\varepsilon^{-3 h} M_{T}^{1-j} \tau^{g-1}}{6 k_{v} \rho_{c} k_{n}}\right]^{\frac{1}{g+3}}
$$

where $\tau$ is residence time $(\mathrm{s}), \mathrm{L}_{\mathrm{m}}$ is median crystal size $(\mathrm{m}), \varepsilon$ is powervolume ratio, $\mathrm{k}_{\mathrm{v}}$ is succinic acid crystal rhombic shape factor [30,64], $\rho_{c}$ is succinic acid crystal density $\left(\mathrm{kg} / \mathrm{m}^{3}\right)$. Because $\mathrm{j}=1$, crystal size and residence time were not functions of magma density. Also, because the growth to nucleation ratio $>1$ and $g>j$, crystal size was a function of residence time. The crystallizer did not include fines removal or crystal size classification. However, a $550 \mu \mathrm{m}$ median crystal size was assumed and corresponded to a low $17.8 \%$ by weight adherence of residual mother liquor [63] that later affects filter cake porosity and reduce downstream rotary drum filter liquid washing costs. As for fermentor, crystallizer magma volume was estimated from volumetric flow rate and residence time.

\section{Economic analysis}

The biorefinery was considered an attractive investment only if recovery of investment period was less than 5 years. All costs were indexed for year 2010. No financial costs were included. Operating costs, investments and their adjustments by capital costs estimated from the materials of construction, etc. for sized units of operation from an ethanol biorefinery were used from literature [37]. Fixed costs were adjusted to include shift operators, shift supervisors, and yard employees for the operation of the downstream processes. The current variable cost of \$60U.S./t of corn stover included harvesting, storage, transportation, and handling costs. A $10 \%$ per year depreciation rate for fixed-capital equipment with no salvage value was assumed. Sensitivity analysis was done to determine production costs when corn stover prices were $\$ 60 / \mathrm{t}$ and increased to $\$ 80$ and $\$ 100 / \mathrm{t}$, assuming a succinic acid yield of 1) that obtained in our baseline simulated process (Scenario A), 2) $15 \%$ (Scenario B), and 3) $19 \%$ (Scenario C). Current and future product market selling prices of $\$ 1 / \mathrm{kg}, \$ 1 / \mathrm{kg}, \$ 0.20 / \mathrm{kg}, \$ 0.30 / \mathrm{kg}$, and $\$ 40 \mathrm{MW} / \mathrm{h}$ for succinic acid, acetic acid, formic acid, ethanol, and generated electricity, respectively, were used to determine annual revenues [65]. Because the targeted product was succinic acid, contributions to total production cost were assumed $60 \%, 5 \%, 5 \%$, and $30 \%$ for succinic acid, acetic acid, formic acid, and ethanol, respectively.

\section{Results and Discussion}

An overall yield of $12.9 \%$ succinic acid, $10 \%$ ethanol, $5.4 \%$ acetic acid, $5.3 \%$ formic acid, and $0.5 \%$ lactic acid from corn stover feedstock was estimated after crystallization for the baseline process (Figure 3). The major process mass flow rates, temperatures, and pressures are depicted (Table 3). For $88542 \mathrm{~kg} / \mathrm{hr}$ of corn stover feedstock, $11453 \mathrm{~kg} /$ hr succinic acid crystal was produced. Estimated area or volume requirements for the downstream units of operation are shown (Table

\begin{tabular}{|l|l|c|}
\hline \multicolumn{1}{|c|}{ Unit of Operation } & \multicolumn{1}{c|}{ Area $\left(\mathrm{m}^{2}\right)$} & Volume $\left(\mathrm{m}^{3}\right)$ \\
\hline Lignin Microfiltration & 6.82 & - \\
\hline Centrifuge & 106.48 & 178.40 \\
\hline Fermentor & - & - \\
\hline Fermentor Cooling Jacket & 46.83 & - \\
\hline Cell Microfiltration & 765 & 25.91 \\
\hline Adsorber & - & - \\
\hline Nanofiltration & 6220 & 17.14 \\
\hline lon Exchanger & - & 16.60 \\
\hline Crystallizer & - & \\
\hline
\end{tabular}

Table 4: Dimensional Requirements of Units of Operation for Simulated Baseline Process.
4). Simulation of microfiltration of insoluble lignin showed that area requirement decreased and pump power consumption increased with increasing recirculation rate (Figure 4 ). The baseline $6 \mathrm{~m} / \mathrm{s}$ recirculation rate consumed $123.325 \mathrm{~kW}$ and resulted in a permeate flux of 0.0048 $\mathrm{m} / \mathrm{s}$.

Using the available baseline kinetic terms of M. succiniciproducens for fermentation resulted in an overall succinic acid $12.9 \%$ yield that was less than the $18.65 \%$ yield from dried biomass from C. glutamicum [5] having unreported kinetic model parameters. However, replacing the M. succiniciproducens succinic acid productivity term $\alpha_{\mathrm{SA}}=1.169$ $(\mathrm{kg} / \mathrm{kg})$ with the $\alpha_{\mathrm{SA}}=3.60(\mathrm{~kg} / \mathrm{kg})$ reported for A. succinogenes, overall succinic yield nearly doubled to $25 \%$, exceeding even the C. glutamicum yield. Such $25 \%$ yield using a term not of C. glutamicum but of the less productive A. succinogenes suggests improvements in both fermentation and our novel downstream recovery and purification are responsible. An optimal dilution rate of $1.20 \mathrm{hr}^{-1}$ corresponding to maximum $M$. succiniciproducens volumetric succinic acid productivity of $69.23 \mathrm{~kg} \mathrm{~m}^{-3} \mathrm{hr}^{-1}$ was predicted graphically (Figure 5) and compared well with the reported maximum M. succiniciproducens specific growth rate of $1.12 \mathrm{hr}^{-1}$ at a dissolved $\mathrm{CO}_{2}$ concentration of $23.3 \mathrm{mM}$ [32].This optimal dilution rate then provided a baseline fermentor liquid volume of $178.29 \mathrm{~m} 3$, liquid height of $12.69 \mathrm{~m}$, and diameter of $4.23 \mathrm{~m}$ as CFD inputs.

The extent that cooling jacket heat transfer area was linearly reduced by increasing $N_{\text {impeller }}$ from $10 \mathrm{rpm}$ to $200 \mathrm{rpm}$ at both $40^{\circ} \mathrm{C}$ and

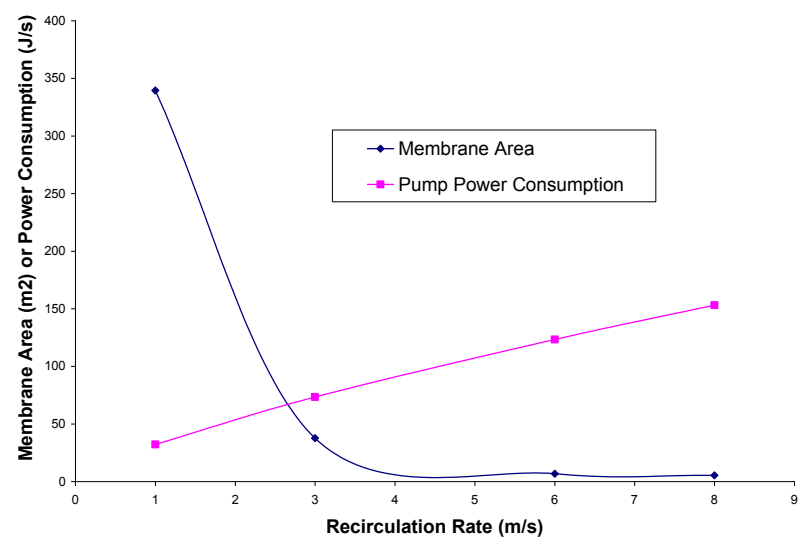

Figure 4: Lignin microfiltration membrane area and power consumption vs recirculation rate.

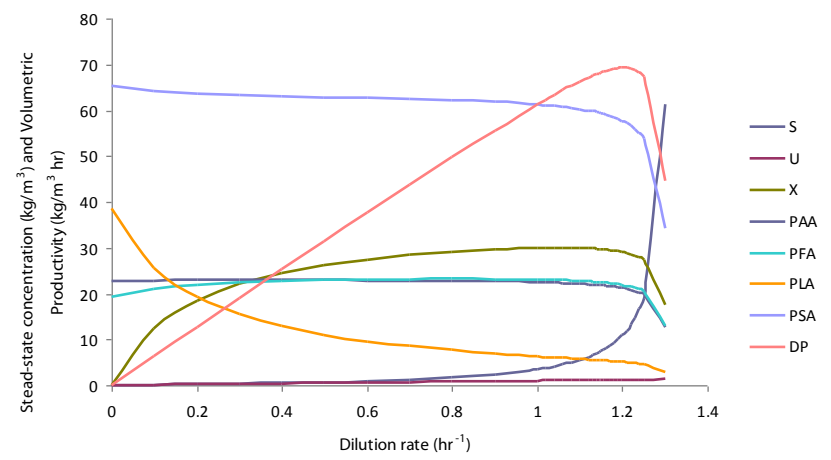

Figure 5: Graphical determination of optimal steady-states and dilution rate for M. succinoproducens fermentor. 
Citation: Wensel P, Yu L, Chen S (2011) Simulation with Computational Fluid Dynamics of Succinic Acid and Co-Product Biorefinery Process. J Bioprocess Biotechniq S2:002 doi:10.4172/2155-9821.S2-002

$42^{\circ} \mathrm{C}$ inlet temperatures were simulated (Figure 6). At inlet $\mathrm{T}_{2}$ of $40^{\circ} \mathrm{C}$, at $200 \mathrm{rpm}$, CFD predicted the average liquid speed of $3.01 \mathrm{~m} / \mathrm{s}, P_{\text {impeller } 0}$ of 433391 Watts, $\mathrm{k}_{\mathrm{L}}$ a of $0.230 \mathrm{~s}^{-1},\left[\mathrm{CO}_{2 L}\right]_{s s}$ of $34.9 \mathrm{mM}$, and of $19.4 \mathrm{~m}^{2}$, $P_{\text {impeller } 0}$ while at $100 \mathrm{rpm}, \mathrm{CFD}$ predicted an average liquid speed of $1.50 \mathrm{~m} / \mathrm{s}$, of 54575.3 Watts, $\mathrm{k}_{\mathrm{L}} \mathrm{a}$ of $0.052 \mathrm{~s}^{-1},\left[\mathrm{CO}_{2 L}\right]_{\mathrm{s}}$ of $33.32 \mathrm{mM}$, and of $55.4 \mathrm{~m} 2$. The $A_{\text {heat }}$ appears to linearly decrease with $N_{\text {impeller }}$ with a regression coefficient of $\mathrm{r}^{2}=0.9896$ as follows:

$$
A_{\text {heat }}=-0.4291 N_{\text {impeller }}+103.47
$$

The predicted $\left[\mathrm{CO}_{2 L}\right]_{s}$ values at these conditions are within the same order of magnitude as the reported $23.3 \mathrm{mM}$ when sparging with pure $\mathrm{CO}^{2}$ at partial pressure of $101.4 \mathrm{kPa}(\mathrm{y}=1)$ in a $2.2 \mathrm{~L}$ liquid volume fermentor at $39^{\circ} \mathrm{C}$ agitated at $200 \mathrm{rpm}$ [32]. Assuming instead an inlet $\mathrm{T}_{2}$ of $42^{\circ} \mathrm{C}$ and minimal $\mathrm{N}_{0}$ of $10 \mathrm{rpm}$, a higher heat term $Q_{\text {removed }}$ of 869993W resulted, and CFD predicted an $A_{\text {heat }}$ of $211.7 \mathrm{~m}^{2}$ exceeding the available fermentor surface area of $168.6 \mathrm{~m}^{2}$. Another external heat exchanger or more efficient spiral-wound cooling coils are therefore necessary for cooling at these impeller and inlet temperature conditions.

The CFD fermentor flow fields simulated at 10rpm, 100rpm, and $200 \mathrm{rpm}$ are visually presented (Figure 7). There is a more pronounced increase in average velocity from 10-100 rpm than from 100-200 rpm. At $200 \mathrm{rpm}$, using instead a graphical power number correlation for power consumption, heat transfer area increases with impeller diameter up to an asymptotic value of $48 \mathrm{~m}^{2}$ corresponding to the impeller diameter of $2 \mathrm{~m}$ (Figure 8 ). The CFD fermentor flow field simulated at $200 \mathrm{rpm}$ for both baseline $178 \mathrm{~m} 3$ and a $78 \mathrm{~m}^{3}$ fermentor are visually presented (Figure 9). Maximum velocity of $16.9 \mathrm{~m} / \mathrm{s}$ and $10.4 \mathrm{~m} / \mathrm{s}$ is predicted for the large and small fermentor, respectively. A 3:1 height to diameter ratio was specified for our process, but future CFD simula-

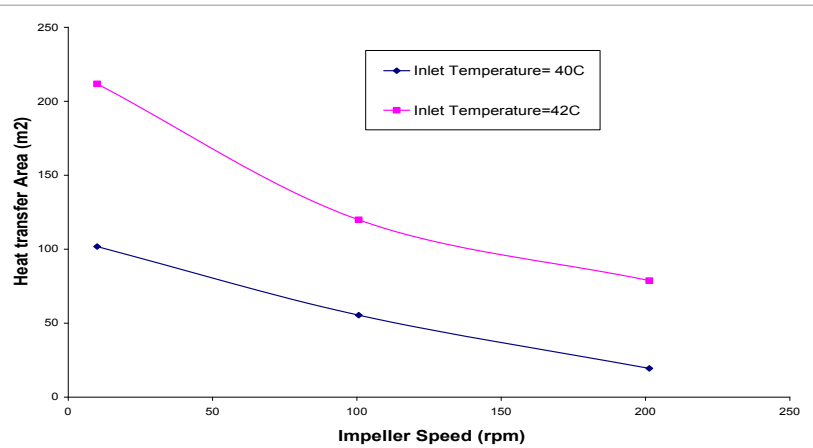

Figure 6: CFD simulation of cooling heat transfer area vs. impeller speed for $178 \mathrm{~m}^{3}$ fermentor.



Figure 7: CFD average liquid velocity flow fields at 10,100 , and $200 \mathrm{rpm}$ in $178 \mathrm{~m}^{3}$ fermentor.

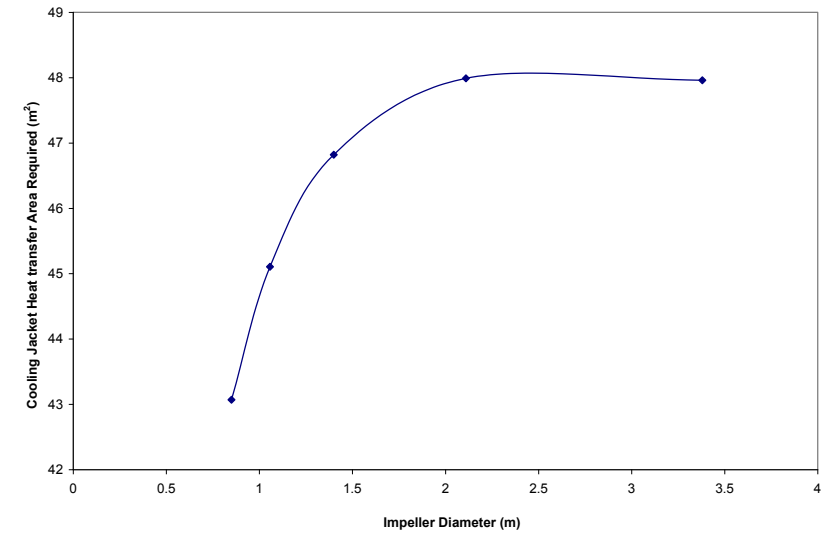

Figure 8: Cooling heat transfer area requirement vs. impeller diameter for $178 \mathrm{~m}^{3}$ fermentor.



Figure 9: CFD liquid velocity flow patterns at $78 \mathrm{~m}^{3}$ and $178 \mathrm{~m}^{3}$ fermentor volumes.

tions can instead predict hydrodynamic changes from varying fermentor height. At minimum, additional hydrostatic head from increased liquid height would impact the gas-liquid $\mathrm{CO}_{2}$ mass transfer of rising bubble flow.

The CFD fermentor flow fields simulated at 200rpm for the smaller $78 \mathrm{~m}^{3}$ fermentor employing either the uniform impeller spacing [46] for the baseline process or a previously described alternate spacing [47] are visually presented (Figure 10). Evidently, the alternate spacing resulted in a higher maximum liquid velocity of $7.92 \mathrm{~m} / \mathrm{s}$ and homogeneity and much less localized mixing, approaching more the assumed CSTR of the baseline process. Using the baseline $200 \mathrm{rpm}$ and uniform impeller spacing, mixing time $\mathrm{t}_{\mathrm{m}}$ was estimated to be $60.67 \mathrm{~s}$ for the 178 $\mathrm{m}^{3}$ fermentor. With greater computational power and resources available, multi-phase CFD fermentor simulations involving sparged $\mathrm{CO}$ gas and liquid can help process engineers optimize flow conditions and scale-up. In addition, mixing time can be used to schedule feeding of $\mathrm{MgCO}_{3}$ solution to both neutralize inhibitory carboxylic acid products and provide a more soluble and storable carbon source than $\mathrm{CO}_{2}$ gas in the fermentor [32].

Although the recycle of cells back to the fermentor after downstream microfiltration recovery was for simplicity not simulated, it is essential to note the potential outcomes if it were. The fermentation industry has long recognized the benefits of cell recycle using membranes or even expanded-bed adsorbers for increasing cell density and volumetric productivity in fermentations, and its mathematical depiction can include such things as a recycle ratio in the mass balances $[66,67]$. In one study, 



Figure 10: CFD liquid velocity flow patterns at alternating and fixed axial impeller spacing for $78 \mathrm{~m}^{3}$ fermentor.

a cell-recycled $A$. succiniciproducens fermentation achieved a high cell concentration of $6.5 \mathrm{~g}$ DCW /L and a three-times higher succinic acid productivity compared to batch culture, without (1) morphologically changing to an inactive spherical state at the stressful high shear rates of $800 \mathrm{rpm}$ that were used to limit membrane fouling, and (2) without becoming $\mathrm{CO}_{2}$-limited even at the highly- consuming recycled high cell densities by virtue of the concurrent supply of both $\mathrm{pH}$ neutralizer and inorganic carbon in the form of $\mathrm{NaHCO}_{3}$ and $\mathrm{Na}_{2} \mathrm{CO}_{3}$ [68].

In another recent instance, succinic acid was produced by Actinobacillus succinogenes sp. $130 \mathrm{Z}$ in an external membrane continuous cell-recycle fermentor [67]. Compared to batch reactor, cell concentration increased three-fold to $16.4 \mathrm{~g} / \mathrm{L}$ at a dilution rate $0.2 \mathrm{~h}^{-1}$, and succinic acid volumetric productivity increased five-fold to $6.63 \mathrm{~g} \mathrm{~L}^{-1} \mathrm{~h}^{-1}$ at a dilution rate of $0.5 \mathrm{~h}^{-1}$ [67]. At high dilution rate, contamination by a lactic acid producer and severe membrane fouling were observed [67]. M. succiniciproducens MBEL55E in this cell-recycle fermentor also achieved a cell concentration and succinic acid productivity at the dilution rate of $0.3 \mathrm{~h}^{-1}$ that were at least 3 and 2.3 times higher, respectively, compared with those at $0.1 \mathrm{~h}^{-1}$ dilution rate [67]. Cell concentration increased with dilution rate, even though it often oscillated before settling to a constant value [67]. Future studies to simulate the effect of such cell recycle, in addition to glucose recycle, and compare productivity gains obtained by either acid neutralization or electrodialysis removal of inhibitory acid levels, should be further done to augment the scope of this current work, as these are expected to positively impact biosuccinic acid production.

Simulation of cell microfiltration with tubes of $0.75 \mathrm{~m}$ length and $0.007 \mathrm{~m}$ inner diameter resulted in a total area requirement and power consumption of $876 \mathrm{~m}^{2}$ and $78.80 \mathrm{~kW}$ for single-stage and a lower 765 $\mathrm{m}^{2}$ and $68.80 \mathrm{~kW}$ for the two-stages of our baseline process. Because permeate flux was predicted using gel polarization theory and was a function of the ratio $\mathrm{C}_{\mathrm{g}} / \mathrm{C}_{\mathrm{o}}$, it was possible to have an intermediary bulk feed cell concentration $\mathrm{C}_{0}$ from the first stage that differed from that of the second stage and resulted in different permeate fluxes for each stage [53].

A primary aim of this work was to simulate a large-scale, continuous succinic acid biorefinery process. Advantages of membrane separation like microfiltration include the ability to operate without phase change, at near ambient temperatures, with relatively low energy consumption. Cross-flow microfiltration for macromolecular insoluble lignin and cells where feed flows parallel to the membrane surface was assumed more suitable for a continuous process than the relatively simpler dead-end filtration configuration requiring lower capital and maintenance costs [69], where the feed contacts the membrane surface at a perpendicular angle. This was primarily due to the intended high retentate concentrations or particle loading of insoluble lignin and cells that may otherwise rapidly compact on the filter surface as a cake layer and increase transmembrane pressure and pumping energy consumption. Also, cross-flow filtration with suitably selected membrane geometry was assumed to be less cumbersome and offer relatively more stable filtration rates and flexibility to periodically backwash or backpulse and reversibly remove some fouling, increasing long-term membrane performance and limiting membrane replacement and labor costs [69].

The M. succiniciproducens MBEL55E being fermented in the baseline simulated process is a rod-shaped bacteria [1]. It is again interesting to note that the morphology of this and other fermented succinic acid-producing anaerobes like A. succinogenes can also become more spherical and less productive for succinic acid due to high inhibitory glucose substrate concentrations above $80 \mathrm{~g} / \mathrm{L}$ [70], which exceeded the calculated $10.89 \mathrm{~g} / \mathrm{L}$ steady-state glucose concentration of this work. Rod-like bacterial morphology, unlike that of yeast cell layers, has in turn also influenced cake resistance differently in both dead-end and cross-flow filtration [71].

Activated carbon adsorption was previously used in downstream succinic acid recovery and purification processes $[8,26]$. Simulation of the GAC adsorption column (Figure 11) resulted in an overall mass transfer coefficient of $5.29 \times 10^{-7} \mathrm{~m} / \mathrm{s}$ and pressure drop of $59 \mathrm{~Pa} / \mathrm{m}$ for the baseline $841 \mu \mathrm{m}$ GAC particle diameter and a coefficient of $7.33 \times 10$ ${ }^{7} \mathrm{~m} / \mathrm{s}$ and pressure drop of $90 \mathrm{~Pa} / \mathrm{m}$ for a $600 \mu \mathrm{m}$ particle diameter. Evidently, greater mass transfer efficiency must be balanced with higher pump power consumption costs.

The resulting nanofiltration retentate concentrations for succinate and lactate were 197.77 and $10.85 \mathrm{~g} / \mathrm{L}$, respectively, while their permeate concentrations were 3.83 and $4.12 \mathrm{~g} / \mathrm{L}$, respectively. A graphical method was used to predict gel-polarization concentration for the nanofiltration unit of the baseline process (Figure 12). For this, only three data points corresponding to succinate concentrations of $0.1,0.2$, and $0.3 \mathrm{M}$ were available from the literature to relate permeate flux with transmembrane pressure [17] but a reasonably high $\mathrm{R}^{2}$ value of 0.9397 was still obtained from these. A gel-polarization concentration value of $303.2 \mathrm{~kg} / \mathrm{m}^{3}$ succinate using the relatively simple gel-polarization model that assumes a steady-state permeate flux to be both independent of transmembrane pressure but dependent on solute concentration was calculated and then used to predict a steady-state flux of $1.42 \times 10^{-6} \mathrm{~m} / \mathrm{s}$ which was the same order magnitude but lower than the experimentally observed $4.44 \times 10^{-6} \mathrm{~m} / \mathrm{s}$ corresponding to $95 \%$ succinate rejection [17] that resulted in a very high area requirement.

Membrane nanofiltration performance depends on the complex in-

Equilibrium Curve and Operating Line for Adsorption of Monosacharides on Granulated Activated Carbon (GAC)



Figure 11: Adsorption equilibrium curve and operating line for glucose removal. 
Steady-State Flux vs. Ln (Sodium Succinate Concentration)

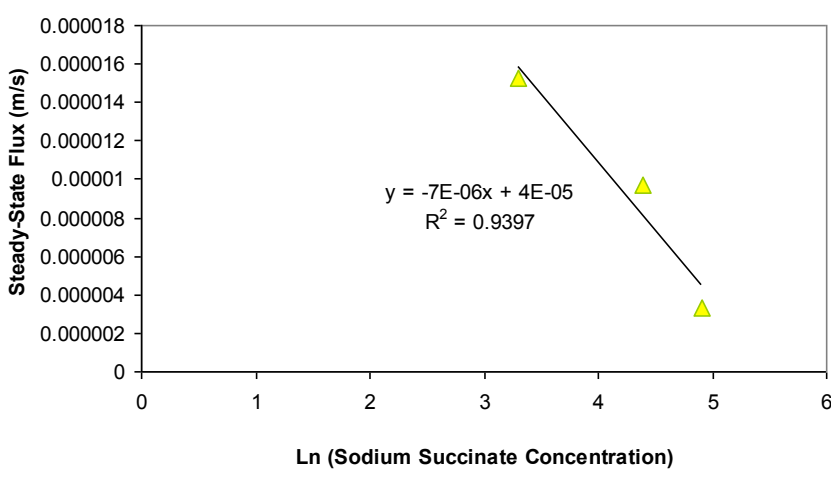

Figure 12: Estimation of gel polarization concentration for nanofiltration.

teraction of many factors, and various models have been developed to try to predict actual phenomena but do not always perfectly succeed, as the results in this study also indicate $[40,42,72,73]$. For instance, molecular weight, molecular size (length and width), acid disassociation constant, hydrophobicity and hydrophilicity, and diffusion coefficient were identified as key solute parameters primarily affecting solute rejection [73]. Also, molecular weight cut-off, pore size, surface charge (measured as zeta potential), hydrophobicity and hydrophilicity (measured as contact angle), and surface morphology (measured as roughness) were identified as key membrane properties primarily affecting rejection [73]. Furthermore, solute rejection was affected by feed composition, like ionic strength, $\mathrm{pH}$, hardness, and organic matter [73]. Another study evaluated the effects of $\mathrm{pH}$, salt concentration, and temperature on the lactate flux and rejection when using a FILMTECTM NF-200B membrane nanofiltration of concentrated organic/inorganic mixtures of salt (up to $17 \%(\mathrm{w} / \mathrm{v}))$ and lactic acid $(2 \%(\mathrm{w} / \mathrm{v}))$. Salt rejection was low, and lactate rejection was highest at neutral $\mathrm{pH}$, decreasing with temperature and salt concentration for all evaluated solutions [27]. The measured flux and rejection values indicated that skin shrinkage in concentrated salt solutions and membrane sorption of lactate influences nanofiltration beyond the typical effects of charge, solute size and osmotic difference between the retentate and permeate streams [27].

According to the literature from which the high 95\% succinate rejection values for simulation were derived, divalent anions of succinate in monovalent anion solutions could also dramatically decrease the rejection of the monovalent anions of formate, lactate, and acetate in the transport through nanofiltration membranes [17]. In this previous work, flux changed with concentration even at identical pressure, and rejection of succinate by NF45 membrane for different concentrations was plotted versus transmembrane pressures and permeate [17]. The succinate rejection increased from 23 to $94 \%$ with flux and mainly depended on the flux independent of the concentration [17]. The typically observed decrease of a solute's rejection with its concentration likely due to the increased screening of membrane surface charge by counterions like sodium was not observed in the cited study because even the lowest $0.1 \mathrm{M}$ concentration of $\mathrm{Na}+$ tested was probably already high enough to fully screen the membrane surface charge [17]. Clearly, this current biorefinery simulation work can be improved with more comprehensive and intensive evaluation of all significant factors affecting succinate rejection in nanofiltration. Operating conditions should as a result be further optimized to exploit this technology enabling nondestructive separation of succinate from other co-products in real-life industrial processes.

Capacity, low-cost regenerability, and specificity for succinate when acidifying and purifying it were factored into the selection of Dowex MWA-1 ion exchange resin and will also be considered in more comprehensive future economic studies. Nonetheless, it was before noted that a final concentration exceeding $100 \mathrm{~g}$ of succinic acid/L was likely economically feasible if achieved with resins that included XUS-40285 and XFS- 40422 that were similarly manufactured by Dow ${ }^{\oplus}$ [59], and, in this work, a concentration of $222.87 \mathrm{~g}$ of succinic acid /L was predicted. As previously mentioned, an ion exchange resin like Amberlite IR-120 that was similarly used to acidify organic salts but that, in contrast, required $\mathrm{HCl}$ or $\mathrm{H}_{2} \mathrm{SO}_{4}$ regeneration, was also viewed as economically favorable to electrodialysis in some instances [18]. As for the fermentor, future multi-phase CFD simulation of crystallizer involving solid succinic acid crystal and liquid mother liquor can be done to assess the effect of impeller speeds on complex crystal nucleation and growth phenomena.

The general biorefinery energy balance is shown (Table 5). Approximately $15938 \mathrm{~kg} / \mathrm{h}$ of lignin was recovered via microfiltration to fuel a boiler to generate steam and electricity, and $47.9 \%$ of the corn-stover feedstock $(42412 \mathrm{~kg} / \mathrm{hr})$ was not converted into products. Lignin-generated steam $\mathrm{m}_{\text {steam }}$ was estimated at $69410 \mathrm{~kg} / \mathrm{hr}$. However, to meet the biorefinery requirement of $154324 \mathrm{~kg} / \mathrm{hr}$ of steam [37], first the steam pressure and temperature were increased by assuming instead that a commercial bubbling fluidized-bed boiler produced up to $160000 \mathrm{~kg} / \mathrm{h}$ of steam at $15 \mathrm{MPa}$ and $\mathrm{T}=450^{\circ} \mathrm{C}$ with $\mathrm{h}_{\text {steam }}=3157 \mathrm{~kJ} / \mathrm{kg}$. Second, $42 \%$ of the biomass lost in the process was assumed recovered to provide the $17863 \mathrm{~kg} / \mathrm{h}$ needed to fuel this new boiler. Since the new assumed steam conditions exceeded pre-hydrolysis requirements, the steam energy content was used to produce extra electricity in a steam turbinegenerator system. Assuming a total efficiency of $52 \%$, corresponding to $65 \%$ efficiency of turbine and $80 \%$ efficiency for generator when steam pressure and temperature drop to $1.36 \mathrm{MPa}$ and $245^{\circ} \mathrm{C}$, respectively, the generated power capacity was $4.2 \mathrm{MW}$, and electricity production was $36847 \mathrm{MWh} /$ year. Total biorefinery power consumption, includ-

\begin{tabular}{|l|l|l|}
\hline \multicolumn{1}{|c|}{ Feedstock/Product } & \multicolumn{1}{c|}{ Energy Content (MJ/h) } & \multicolumn{1}{c|}{ \% of Total } \\
\hline Dry corn-stover biomass & 1416667 & 100 \\
\hline Electricity & 15120 & 1.1 \\
\hline Ethanol & 141667 & 10 \\
\hline Lactic Acid & 13161 & 0.9 \\
\hline Acetic Acid & 153021 & 10.8 \\
\hline Formic Acid & 149147 & 10.6 \\
\hline Succinic Acid & 367641 & 26 \\
\hline Steam+ Hot Water & 511142 & 36 \\
\hline Losses & 65173 & 4.6 \\
\hline
\end{tabular}

Table 5: General energy balance for succinic acid biorefinery process.

\begin{tabular}{|l|l|}
\hline Description of Analyzed Economic Parameter & US \$ \\
\hline Total Project Investment(installed equipment and indirect costs) & $2.93 \mathrm{E}+08$ \\
\hline Annual Fixed Operating Costs (i.e. labor, overhead) & 11504720 \\
\hline Annual Variable Operating Costs (i.e. feedstock, cooling water, etc.) & 55756068 \\
\hline Annual Depreciation costs & 34367862 \\
\hline $\begin{array}{l}\text { Annual Revenues (Assumes product and lignin-electricity selling } \\
\text { prices and yields }\end{array}$ & $1.75 \mathrm{E}+08$ \\
\hline Annual Income & 73207273 \\
\hline Return on Investment Period & 4.00 \\
\hline
\end{tabular}

Table 6: Summary of Biorefinery Economic Analysis. 
Citation: Wensel P, Yu L, Chen S (2011) Simulation with Computational Fluid Dynamics of Succinic Acid and Co-Product Biorefinery Process. J Bioprocess Biotechniq S2:002 doi:10.4172/2155-9821.S2-002

Page 14 of 17

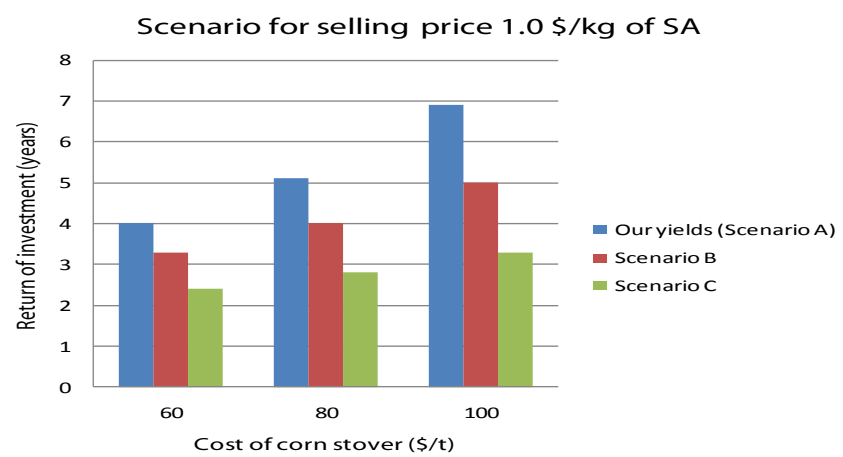

Figure 13: Periods of return of investment for succinic acid selling price of $\$ 1$ U.S./kg.

ing that estimated from CFD for the fermentor, was estimated as 8561 $\mathrm{MWh} /$ year. The difference between energy generated and consumed (27847 MWh/year) was therefore exported to the grid for $\$ 1131420$ / year of revenues.

By integrating costs and capital investments literature data for ethanol biorefineries [37] with feedstock costs, product pricing, and the predicted product yields and steam generation of the baseline simulated succininc acid biorefinery process, the rough estimates of costs, revenues, and income for the baseline succinic acid bioprocess were obtained and are shown (Table 6). Corn stover raw material represented the highest variable operating cost. Assuming a \$1 U.S./kg succinic acid selling price for scenarios involving our $12.9 \%$ baseline yield, $15 \%$, and $19 \%$, the effect of increasing corn stover costs on ROI period is summarized (Figure 13). The succinic biorefinery was therefore profitable and attractive with an ROI period of 5 years or less only if succinic acid selling exceeded $\$ 1.6 / \mathrm{kg}$.

\section{Conclusion}

A novel industrial-scale biorefinery succinic acid process was described and integrated pre-treatment and hydrolysis with lignin removal and recovery to provide on-site steam and electricity generation, glucose removal and recovery, and non-destructive nanofltration succinate separation. A multi-unit process model was developed for important units of operation to enable future optimization. For the fermentor, Computational Fluid Dynamics (CFD) through its coupling to the kinetics, mass and energy balances was demonstrated to be a valuable and useful tool for scale-up. The succinic acid biorefinery was considered profitable and attractive only if the selling price of the succinic acid exceeded $\$ 1.6 / \mathrm{kg}$. This work represents the first reported industrial-scale process design model for biochemically-derived succinic acid.

\section{Acknowledgment}

The work was funded by the Washington State University

\section{Nomenclature}

\begin{tabular}{|c|l|c|l|}
\hline$J_{c}$ & $\begin{array}{l}\text { critical permeate flux, } \\
\mathrm{m} / \mathrm{s}\end{array}$ & & \\
\hline$\rho_{p}$ & $\begin{array}{l}\text { permeate density, } \mathrm{kg} / \\
\mathrm{m}^{3}\end{array}$ & $N_{\text {impeller }}$ & rotational impeller speed, $\mathrm{rps}$ \\
\hline$\mu_{p}$ & $\begin{array}{l}\text { permeate viscosity, } \\
\mathrm{Pa}{ }^{*} \mathrm{~s}\end{array}$ & $y$ & $\mathrm{CO}_{2}$ mass fraction \\
\hline $\mathrm{r}$ & lignin particle radius, $\mathrm{m}$ & $d_{\text {cell }}$ & equivalent cell diameter, $\mathrm{m}$ \\
\hline $\mathrm{V}_{\mathrm{w}}$ & $\begin{array}{l}\text { tubular wall shear } \\
\text { rate, } \mathrm{s}^{-1}\end{array}$ & $D_{\text {impeller }}$ & impeller diameter, $\mathrm{m}$ \\
\hline
\end{tabular}

\begin{tabular}{|c|c|c|c|}
\hline$P_{\text {micro-1 }}$ & $\begin{array}{l}\text { pump power consump- } \\
\text { tion, J/s }\end{array}$ & $v_{l}$ & dynamic viscosity, $\mathrm{m}^{2} / \mathrm{s}$ \\
\hline$U_{\text {micro-1 }}$ & recirculation rate, $\mathrm{m} / \mathrm{s}$ & c & death rate constant, $\mathrm{m}^{3} / \mathrm{s}$ \\
\hline$\eta_{p}$ & pump efficiency & $P_{S A s s}$ & $\begin{array}{l}\text { steady-state concentration of } \\
\text { succinic acid, } \mathrm{kg} / \mathrm{m}^{3}\end{array}$ \\
\hline M & impeller torque, $\mathrm{N} \cdot \mathrm{m}$ & $P_{A A s s}$ & $\begin{array}{l}\text { steady-state concentration of } \\
\text { acetic acid, } \mathrm{kg} / \mathrm{m}^{3}\end{array}$ \\
\hline $\mathrm{d}_{\text {micro-1 }}$ & tube inner diameter, $\mathrm{m}$ & $P_{\text {LAss }}$ & $\begin{array}{l}\text { steady-state concentration of } \\
\text { lactic acid, } \mathrm{kg} / \mathrm{m}^{3}\end{array}$ \\
\hline$\mu$ & specific growth rate, $\mathrm{s}^{-1}$ & $P_{F A s s}$ & $\begin{array}{l}\text { steady-state concentration of } \\
\text { formic acid, } \mathrm{kg} / \mathrm{m}^{3}\end{array}$ \\
\hline$\Sigma$ & $\begin{array}{l}\text { centrifuge Sigma fac- } \\
\text { tor, } \mathrm{m}^{2}\end{array}$ & $\alpha_{S A}$ & $\begin{array}{l}\text { growth-associated productiv- } \\
\text { ity term for succinic acid, } \\
\mathrm{kg} / \mathrm{kg}\end{array}$ \\
\hline$F$ & $\begin{array}{l}\text { inlet/outlet volumetric } \\
\text { flow rate, } \mathrm{m}^{3} / \mathrm{s}\end{array}$ & $\alpha_{A A}$ & $\begin{array}{l}\text { growth-associated productiv- } \\
\text { ity term for acetic acid, } \mathrm{kg} / \mathrm{kg}\end{array}$ \\
\hline$X_{s s}$ & $\begin{array}{l}\text { steady-state biomass } \\
\text { concentration }(\mathrm{kg} \\
\left.\mathrm{DCW} / \mathrm{m}^{3}\right)\end{array}$ & $\alpha_{L A}$ & $\begin{array}{l}\text { growth-associated productiv- } \\
\text { ity term for lactic acid, } \mathrm{kg} / \mathrm{kg}\end{array}$ \\
\hline $\operatorname{Re}$ & Reynolds number & $\alpha_{F A}$ & $\begin{array}{l}\text { growth-associated productiv- } \\
\text { ity term for formic acid, } \mathrm{kg} / \mathrm{kg}\end{array}$ \\
\hline$X_{0}$ & $\begin{array}{l}\text { feed cell biomass con- } \\
\text { centration, } \mathrm{kg} \mathrm{DCW} / \mathrm{m}^{3}\end{array}$ & $\beta_{S A}$ & $\begin{array}{l}\text { non-growth associated } \\
\text { productivity terms for succinic } \\
\text { acid, } \mathrm{kg} / \mathrm{kg}\end{array}$ \\
\hline$V_{L}$ & $\begin{array}{l}\text { fermentor liquid vol- } \\
\text { ume, } \mathrm{m}^{3}\end{array}$ & $\beta_{A A}$ & $\begin{array}{l}\text { non-growth associated } \\
\text { productivity terms for acetic } \\
\text { acid, } \mathrm{kg} / \mathrm{kg}\end{array}$ \\
\hline$k_{d}$ & specific death rate, $\mathrm{s}^{-1}$ & $\beta_{L A}$ & $\begin{array}{l}\text { non-growth associated } \\
\text { productivity terms for lactic } \\
\text { acid,kg/kg }\end{array}$ \\
\hline$\mu_{\max }$ & $\begin{array}{l}\text { maximum specific } \\
\text { growth rate, } \mathrm{s}^{-1}\end{array}$ & $\beta_{F A}$ & $\begin{array}{l}\text { non-growth associated } \\
\text { productivity terms for formic } \\
\text { acid, } \mathrm{kg} / \mathrm{kg}\end{array}$ \\
\hline$K_{S}$ & $\begin{array}{l}\text { glucose substrate half- } \\
\text { saturation constant, } \\
\mathrm{kg} / \mathrm{m}^{3}\end{array}$ & $S_{0}$ & $\begin{array}{l}\text { glucose substrate feed con- } \\
\text { centration, } \mathrm{kg} / \mathrm{m}^{3}\end{array}$ \\
\hline$S_{s s}$ & $\begin{array}{l}\text { steady-state glucose } \\
\text { substrate concentra- } \\
\text { tion, } \mathrm{kg} / \mathrm{m}^{3}\end{array}$ & & $\begin{array}{l}\text { the inverse effective Prandtl } \\
\text { numbers }\end{array}$ \\
\hline$m_{s}$ & $\begin{array}{l}\text { glucose substrate main- } \\
\text { tenance term, kg/kg }\end{array}$ & $P_{\text {impeller } 0}$ & $\begin{array}{l}\text { non-aerated impeller power } \\
\text { consumption, J/s }\end{array}$ \\
\hline$Y_{x / s}$ & $\begin{array}{l}\text { yield coefficient of } \\
\text { biomass from glucose } \\
\text { substrate, } \mathrm{kg} / \mathrm{kg}\end{array}$ & $N_{p}$ & power number \\
\hline$Y_{S A / s}$ & $\begin{array}{l}\text { yield coefficient of suc- } \\
\text { cinic acid from glucose } \\
\text { substrate, } \mathrm{kg} / \mathrm{kg}\end{array}$ & $\mu_{f}$ & $\begin{array}{l}\text { fermentation broth dynamic } \\
\text { viscosity, } \mathrm{Pa}^{*} \mathrm{~s}\end{array}$ \\
\hline$Y_{A A / s}$ & $\begin{array}{l}\text { yield coefficient of ace- } \\
\text { tic acid from glucose } \\
\text { substrate, } \mathrm{kg} / \mathrm{kg}\end{array}$ & $\mathrm{t}_{\mathrm{m}}$ & mixing time, $\mathrm{s}$ \\
\hline$Y_{L A / s}$ & $\begin{array}{l}\text { yield coefficient of } \\
\text { lactic acid from glucose } \\
\text { substrate, } \mathrm{kg} / \mathrm{kg}\end{array}$ & $P_{\text {impellerg }} \mu$ & $\begin{array}{l}\text { Aerated power consump- } \\
\text { tion, J/s }\end{array}$ \\
\hline$Y_{F A / s}$ & $\begin{array}{l}\text { yield coefficient of for- } \\
\text { mic acid from glucose } \\
\text { substrate, } \mathrm{kg} / \mathrm{kg}\end{array}$ & $F_{g}$ & volumetric $\mathrm{CO}_{2}$ flow rate, $\mathrm{m}^{3} / \mathrm{s}$ \\
\hline$D$ & dilution rate, $\mathrm{s}^{-1}$ & $g$ & gravitational constant, $\mathrm{m}^{2} / \mathrm{s}$ \\
\hline$D_{T}$ & fermentor diameter, $\mathrm{m}$ & $H_{\text {impeller }}$ & height of impeller blade, $\mathrm{m}$ \\
\hline$N_{0}$ & $\begin{array}{l}\text { minimum impeller } \\
\text { speed, rps }\end{array}$ & $k_{L} a$ & $\begin{array}{l}\text { volumetric gas-liquid mass } \\
\text { transfer coefficient, } \mathrm{s}^{-1}\end{array}$ \\
\hline$\sigma$ & surface tension, dyne/m & $v_{g}$ & $\begin{array}{l}\text { superficial } \mathrm{CO}_{2} \text { gas velocity, } \\
\mathrm{m} / \mathrm{s}\end{array}$ \\
\hline$\rho_{f}$ & $\begin{array}{l}\text { fermentation broth } \\
\text { density, } \mathrm{kg} / \mathrm{m}^{3}\end{array}$ & $F_{i_{i n}}$ & $\begin{array}{l}\text { inlet mass flow rates of com- } \\
\text { ponents } \mathrm{i}, \mathrm{kg} / \mathrm{s}\end{array}$ \\
\hline$\left[\mathrm{CO}_{2 L}\right]_{s}$ & $\begin{array}{l}\text { steady-state } \mathrm{CO}_{2} \text { liquid- } \\
\text { phase concentration, } \\
\mathrm{kg} / \mathrm{m}^{3}\end{array}$ & $F_{i_{\text {out }}}$ & $\begin{array}{l}\text { outlet mass flow rates of } \\
\text { components } \mathrm{i}, \mathrm{kg} / \mathrm{s}\end{array}$ \\
\hline
\end{tabular}


Citation: Wensel P, Yu L, Chen S (2011) Simulation with Computational Fluid Dynamics of Succinic Acid and Co-Product Biorefinery Process. J Bioprocess Biotechniq S2:002 doi:10.4172/2155-9821.S2-002

\begin{tabular}{|c|c|c|c|}
\hline$\left[\mathrm{CO}_{2}\right]$ & $\begin{array}{l}\text { inlet } \mathrm{CO}_{2} \text { concentration, } \\
\mathrm{kg} / \mathrm{m}^{3}\end{array}$ & $H_{i_{i n}}$ & $\begin{array}{l}\text { inlet mass enthalpy of compo- } \\
\text { nents } \mathrm{i}, \mathrm{J} / \mathrm{kg}\end{array}$ \\
\hline$H$ & $\begin{array}{l}\text { Henry's Law } \\
\text { constant,Pa kg CO} / \mathrm{m}^{3}\end{array}$ & $H_{i_{\text {out }}}$ & $\begin{array}{l}\text { outlet mass enthalpy of com- } \\
\text { ponents } \mathrm{i}, \mathrm{J} / \mathrm{kg}\end{array}$ \\
\hline$P$ & total pressure, $\mathrm{Pa}$ & $H_{i}^{o}\left(T_{R}\right)$ & $\begin{array}{l}\text { heat of combustion for com- } \\
\text { ponent i, J/kg at reference } \\
\text { temperature TR }\end{array}$ \\
\hline$r_{\mathrm{Co}_{2}}$ & $\begin{array}{l}\text { rate of consumption of } \\
\mathrm{CO}_{2}, \mathrm{~kg} / \mathrm{s}\end{array}$ & $\mathrm{T}_{2}$ & $\begin{array}{l}\text { inlet or outlet liquid tempera- } \\
\text { ture, }{ }^{\circ} \mathrm{C}\end{array}$ \\
\hline$K_{g} a$ & $\begin{array}{l}\text { overall gas phase mass } \\
\text { transfer coefficient, } \mathrm{kg} / \\
\mathrm{Pa}^{*} \mathrm{~S}\end{array}$ & $C_{p_{i}}$ & $\begin{array}{l}\text { heat capacity of component } \mathrm{i} \text {, } \\
\mathrm{J} \mathrm{kg}^{-1}{ }^{\circ} \mathrm{C}^{-1}\end{array}$ \\
\hline$k_{g} a$ & $\begin{array}{l}\text { local gas phase mass } \\
\text { transfer coefficient, kg/ } \\
\mathrm{Pa}^{*} \mathrm{~s}\end{array}$ & $H_{\text {cell }}^{o}$ & $\begin{array}{l}\text { Heat of combustion biomass } \\
\text { enthalpy, J/kg }\end{array}$ \\
\hline$\left[\mathrm{CO}_{2}\right]$ & $\begin{array}{l}\text { inlet liquid-phase con- } \\
\text { centration, } \mathrm{kg} / \mathrm{m}^{3}\end{array}$ & C & weight fractions of carbon \\
\hline$\left[\mathrm{CO}_{2 G}\right]$ & $\begin{array}{l}\text { inlet gas-phase concen- } \\
\text { tration, } \mathrm{kg} / \mathrm{m}^{3}\end{array}$ & $\mathrm{O}$ & weight fractions of oxygen \\
\hline \multirow[t]{2}{*}[\mathrm{CO}_{2G}]{$_{\mathrm{ss}}$} & $\begin{array}{l}\text { steady-state gas-phase } \\
\mathrm{CO}_{2} \text { concentration exit- } \\
\text { ing fermentor, } \mathrm{kg} / \mathrm{m}^{3}\end{array}$ & $\mu \mathrm{H}$ & weight fractions of hydrogen \\
\hline & & $A_{\text {heat }}$ & $\begin{array}{l}\text { Fermentor cooloing jacket } \\
\text { area requirement, } \mathrm{m}^{2}\end{array}$ \\
\hline$F_{\mathrm{CO} 2 g-o u t}$ & $\begin{array}{l}\text { exiting } \mathrm{CO}_{2} \text { gas mass } \\
\text { flow rate, } \mathrm{kg} / \mathrm{s}\end{array}$ & $D_{\text {cell }}$ & $\begin{array}{l}\text { particle diffusion coefficient } \\
\text { of cells in fermentation broth, } \\
\mathrm{m}^{2} / \mathrm{s}\end{array}$ \\
\hline$F_{\text {watervapor }}$ & $\begin{array}{l}\text { exiting water vapor } \\
\text { mass flow rate. } \mathrm{kg} / \mathrm{s}\end{array}$ & $\mathrm{L}_{\text {micro-2 }}$ & tube length, $m$ \\
\hline$Q_{\text {removed }}$ & $\begin{array}{l}\text { rate of heat to be } \\
\text { removed, } \mathrm{J} / \mathrm{s}\end{array}$ & Y & Microfiltration shear rate, $\mathrm{s}^{-1}$ \\
\hline$\eta_{\text {impeller }}$ & $\begin{array}{l}\text { impeller gearbox ef- } \\
\text { ficiency }\end{array}$ & $\mathrm{C}_{\text {gcel }} \mathrm{l}$ & $\begin{array}{l}\text { gel polarization volume } \\
\text { fraction }\end{array}$ \\
\hline$U$ & $\begin{array}{l}\text { overall heat transfer } \\
\text { coefficient, } \mathrm{W} / \mathrm{m} 2-^{\circ} \mathrm{C}\end{array}$ & $\mathrm{C}_{\text {oce }} \mathrm{II}$ & bulk cell volume fraction \\
\hline $\mathrm{T}_{\mathrm{c}}$ & $\begin{array}{l}\text { average cooling water } \\
\text { temperature, }{ }^{\circ} \mathrm{C}\end{array}$ & $\mathrm{q}_{\mathrm{glu}}$ & $\begin{array}{l}\text { glucose concentration in GAC } \\
\text { sorbent phase, mol glucose/ } \\
\text { kg GAC sorbent }\end{array}$ \\
\hline $\mathrm{T}_{\mathrm{F}}$ & $\begin{array}{l}\text { fermentation broth } \\
\text { temperature, },{ }^{\circ} \mathrm{C}\end{array}$ & $\mathrm{qm}$ & $\begin{array}{l}\text { maximum sorbent capacity, } \\
\text { mol glucose/kg GAC sorbent }\end{array}$ \\
\hline$h_{F}$ & $\begin{array}{l}\text { heat transfer coefficient } \\
\text { for the fermentation } \\
\text { broth, } \mathrm{W} / \mathrm{m}^{2}-^{\circ} \mathrm{C}\end{array}$ & Cglu & $\begin{array}{l}\text { glucose concentration in liquid } \\
\text { phase, mol glucose /m3 feed } \\
\text { solution }\end{array}$ \\
\hline$h_{F D}$ & $\begin{array}{l}\text { dirt factor from fermen- } \\
\text { tation broth, } \mathrm{W} / \mathrm{m}^{2}-{ }^{\circ} \mathrm{C}\end{array}$ & NTU & Number of Transfer Units \\
\hline$k_{W}$ & $\begin{array}{l}\text { thermal conductivity of } \\
\text { fermentor wall, } \mathrm{J} / \mathrm{m}^{2}\end{array}$ & HTU & Height of Transfer Units,m \\
\hline$\Delta x$ & $\begin{array}{l}\text { fermentor wall thick- } \\
\text { ness, } m\end{array}$ & $\mathrm{~K}_{\text {adsorber }}$ & $\begin{array}{l}\text { overall mass transfer coef- } \\
\text { ficient, } \mathrm{m} / \mathrm{s}\end{array}$ \\
\hline$h_{C}$ & $\begin{array}{l}\text { cooling water heat } \\
\text { transfer coefficient, W/ } \\
\mathrm{m}^{2}-^{\circ} \mathrm{C}\end{array}$ & $\mathrm{V}_{\text {adsorber }}$ & $\begin{array}{l}\text { Adsorber hydraulic loading } \\
\text { rate, } \mathrm{m} / \mathrm{s}\end{array}$ \\
\hline$h_{C D}$ & $\begin{array}{l}\text { cooling water dirt factor } \\
\text { heat transfer coef- } \\
\text { ficient, } \mathrm{W} / \mathrm{m}^{2}{ }^{\circ} \mathrm{C}\end{array}$ & $a_{i}$ & $\begin{array}{l}\text { particle interfacial area/vol- } \\
\text { ume ratio, } \mathrm{m}^{-1}\end{array}$ \\
\hline$\mu_{W}$ & wall viscosity, $\mathrm{kg} / \mathrm{s}-\mathrm{m}$ & $\mathrm{SBH}$ & stochiometric bed height,m \\
\hline$k_{F}$ & $\begin{array}{l}\text { fermentation broth } \\
\text { thermal conductivity, } \\
\mathrm{W} / \mathrm{m}-{ }^{\circ} \mathrm{C}\end{array}$ & LUB & length of unused bed, $m$ \\
\hline $\mathrm{J}_{\text {micro-2 }}$ & $\begin{array}{l}\text { microfiltration steady- } \\
\text { state permeate flux, } \\
\mathrm{m} / \mathrm{s}\end{array}$ & $\mathrm{L}_{1}$ & $\begin{array}{l}\text { length of small-scale column, } \\
\mathrm{m}\end{array}$ \\
\hline$\varepsilon$ & $\begin{array}{l}\text { bed porosity or void } \\
\text { fraction }\end{array}$ & $t_{b}$ & $\begin{array}{l}\text { breakthrough time for succinic } \\
\text { acid, s }\end{array}$ \\
\hline$d_{p}$ & $\begin{array}{l}\text { GAC particle diameter, } \\
\mathrm{m}\end{array}$ & $t^{*}$ & $\begin{array}{l}\text { midpoint time for succinic } \\
\text { acid, s }\end{array}$ \\
\hline
\end{tabular}

\begin{tabular}{|c|c|c|c|}
\hline $\mathrm{k}_{\mathrm{film}}$ & $\begin{array}{l}\text { film-mass transfer coef- } \\
\text { ficient, } \mathrm{m} / \mathrm{s}\end{array}$ & $v_{\text {ion }}$ & $\begin{array}{l}\text { ion-exchanger hydraulic load- } \\
\text { ing rate, } \mathrm{m} / \mathrm{s}\end{array}$ \\
\hline $\mathrm{k}_{\mathrm{s}}$ & $\begin{array}{l}\text { intra-particle mass } \\
\text { transfer coefficient, } \mathrm{m} / \mathrm{s}\end{array}$ & $\mathrm{q}_{0} / \mathrm{c}_{\mathrm{o}}$ & $\begin{array}{l}\text { ratio of feed succinate } \\
\text { liquid-phase concentration } \\
\text { to Dowex sorbent succinate } \\
\text { solid phase-concentration in } \\
\text { equilibrium }\end{array}$ \\
\hline $\mathrm{k}_{\text {nano }}$ & $\begin{array}{l}\text { succinate mass transfer } \\
\text { coefficient, } \mathrm{m} / \mathrm{s}\end{array}$ & $t_{s}$ & service time(s) \\
\hline$C_{\text {g-suc }}$ & $\begin{array}{l}\text { Succinate gel polariza- } \\
\text { tion concentration, } \\
\mathrm{kg} / \mathrm{m}^{3}\end{array}$ & $Y_{\text {cry }}$ & $\begin{array}{l}\text { maximum yield rate of crystal } \\
\text { produced, } \mathrm{kg} / \mathrm{s}\end{array}$ \\
\hline $\mathrm{C}_{\text {o-suc }}$ & $\begin{array}{l}\text { bulk feed concentration } \\
\text { of succinate, } \mathrm{kg} / \mathrm{m}^{3}\end{array}$ & sow & $\begin{array}{l}\text { weight of original free solvent } \\
\text { water, } \mathrm{kg} / \mathrm{s}\end{array}$ \\
\hline$J_{\text {nano }}$ & $\begin{array}{l}\text { nanofiltration steady- } \\
\text { state permeate flux, } \\
\mathrm{m} / \mathrm{s}\end{array}$ & $V_{d}$ & $\begin{array}{l}\text { added diluent, } \mathrm{kg} / \mathrm{kg} \text { original } \\
\text { free solvent water }\end{array}$ \\
\hline $\mathrm{R}_{\mathrm{h}}$ & $\begin{array}{l}\text { ratio of molecular } \\
\text { weights of hydrate and } \\
\text { anhydrous salts }\end{array}$ & $V_{e}$ & $\begin{array}{l}\text { solvent loss from evaporation, } \\
\mathrm{kg} / \mathrm{kg} \text { original free solvent } \\
\text { water }\end{array}$ \\
\hline B & $\begin{array}{l}\text { crystal nucleation } \\
\text { rate, } \mathrm{s}^{-1}\end{array}$ & $\mathrm{C}_{\text {osuc-cry }}$ & $\begin{array}{l}\text { initial concentration of suc- } \\
\text { cinic acid crystal in feed, kg } \\
\text { anhydrous succinic acid/kg } \\
\text { free solvent water }\end{array}$ \\
\hline G & crystal growth rate, $\mathrm{s}^{-1}$ & $\mathrm{C}_{\text {Fsuc-cry }}$ & $\begin{array}{l}\text { final concentration of suc- } \\
\text { cininc acid in saturated } \\
\text { mother liquor, } \mathrm{kg} \text { anhydrous } \\
\text { succinic acid/kg free solvent } \\
\text { water }\end{array}$ \\
\hline $\mathrm{N}_{\mathrm{cry}}$ & $\begin{array}{l}\text { crystallizer impeller } \\
\text { speed (rps) }\end{array}$ & $z$ & Crystallizer exponent \\
\hline$M_{T}$ & $\begin{array}{l}\text { magma density, } \mathrm{kg} \\
\text { succinic acid crystal/m3 } \\
\text { mother liquor }\end{array}$ & $v$ & Crystallizer exponent \\
\hline $\mathrm{k}_{\mathrm{n}}$ & Crystallizer coefficient & $b$ & Crystallizer exponent \\
\hline $\mathrm{k}_{\mathrm{g}}$ & Crystallizer coefficient & j & Crystallizer exponent \\
\hline$k_{B}$ & Crystallizer coefficient & $\mathrm{s}$ & Crystallizer exponent \\
\hline$L_{m}$ & median crystal size, $\mathrm{m}$ & $\mathrm{h}$ & Crystallizer exponent \\
\hline $\mathrm{T}$ & $\begin{array}{l}\text { Crystallizer residence } \\
\text { time (s) }\end{array}$ & $\mathrm{k}_{\mathrm{v}}$ & $\begin{array}{l}\text { succinic acid crystal rhombic } \\
\text { shape factor }\end{array}$ \\
\hline$\varepsilon$ & power-volume ratio & $\rho_{c}$ & $\begin{array}{l}\text { succinic acid crystal density, } \\
\mathrm{kg} / \mathrm{m}_{3}\end{array}$ \\
\hline$\Delta c$ & supersaturation, $\mathrm{kg} / \mathrm{m}_{3}$ & $A_{\text {micro-1 }}$ & Area requirement $\left(\mathrm{m}^{2}\right)$ \\
\hline
\end{tabular}

\section{References}

1. Song H, Lee SY (2006) Production of succinic acid by bacterial fermentation. Enzyme and Microbial Technology 39: 352-361.

2. Zeikus JG, Jain MK, Elankovan P (1999) Biotechnology of succinic acid production and markets for derived industrial products. Appl Microbiol Biotechno 51: 545-552.

3. Beauprez JJ, De Mey M, Soetaert WK (2010) Microbial succinic acid production: Natural versus metabolic engineered producers. Process Biochemistry 45 : 1103-1114.

4. Lynd LR, Wyman C, Laser M, Johnson D, Landucci R (2005) Strategic biorefinery analysis: Analysis of biorefineries. NREL Subcontractor Report SR-51035578 National Renewable Energy Laboratory: Golden, Colorado.

5. Luo L, van der Voet E, Huppes G (2010) Biorefining of lignocellulosic feedstock - Technical, economic and environmental considerations. Bioresource Technology 101: 5023-5032.

6. Song H, Jang SH, Park JM, Lee SY (2008) Modeling of batch fermentation kinetics for succinic acid production by Mannheimia succiniciproducens. Biochemical Engineering Journal 40: 107-115.

7. Werpy T, Petersen G, Aden A, Bozell J, Holladay J, et al. (2004) Top value added chemicals from biomass. Volume I, Pacific Northwest National Laboratory, Richland, Washington.

8. Lin SKC, Du C, Blaga AC, Camarut M, Webb C, et al. (2010) Novel resin-based 
Citation: Wensel P, Yu L, Chen S (2011) Simulation with Computational Fluid Dynamics of Succinic Acid and Co-Product Biorefinery Process. J Bioprocess Biotechniq S2:002 doi:10.4172/2155-9821.S2-002

Page 16 of 17

vacuum distillation-crystallisation method for recovery of succinic acid crystals from fermentation broths. Green Chem 12: 666-671.

9. McCoy M (2009) Big plans for succinic acid. Chemical \& Engineering News 87: $23-25$

10. Elbert J (2007) The quest to commercialize biobased succinic-acid. Biomass Magazine.

11. Yu J, Li ZM, Ye Q, Yang Y, Chen SL (2010) Development of succinic acid production from corncob hydrolysate by Actinobacillus succinogenes. Journal of Industrial Microbiology \& Biotechnology 37: 1033-1040.

12. Luque R, Lin CSK, Du C, Macquarrie DJ, Koutinas A, et al. (2009) Chemica transformations of succinic acid recovered from fermentation broths by a nove direct vacuum distillation-crystallisation method. Green Chem 11: 193-200.

13. Song H, Huh YS, Lee SY, Hong WH, Hong YK (2007) Recovery of succinic acid produced by fermentation of a metabolically engineered Mannheimia succiniciproducens strain. J Biotechnol 132: 445-452.

14. Li J, Zheng XY, Fang XJ, Liu SW, Chen KQ, et al. (2011) A complete industrial system for economical succinic acid production by Actinobacillus succinogenes. Bioresource Technology 102: 6147-6152.

15. Huh YS, Jun YS, Hong YK, Song H, Lee SY, et al. (2006) Effective purification of succinic acid from fermentation broth produced by Mannheimia succiniciproducens. Process Biochemistry 41: 1461-1465

16. Li Q, Wang D, Wu Y, Li W, Zhang Y, et al. (2010) One step recovery of succinic acid from fermentation broths by crystallization. Separation and Purification Technology 72: 294-300.

17. Kang SH, Chang YK (2005) Removal of organic acid salts from simulated fermentation broth containing succinate by nanofiltration. Journal of Membrane Science 246: 49-57.

18. Wang $Y$, Huang $C, X u T$ (2011) Which is more competitive for production of organic acids, ion-exchange or electrodialysis with bipolar membranes? Journal of Membrane Science 374: 150-156.

19. Meynial-Salles I, Dorotyn S, Soucaille P (2008) A new process for the continuous production of succinic acid from glucose at high yield, titer, and productivity. Biotechnology and Bioengineering 99: 129-135.

20. Huang C, Xu T, Zhang Y, Xue Y, Chen G (2007) Application of electrodialysis to the production of organic acids: State-of-the-art and recent developments. Journal of Membrane Science 288: 1-12.

21. Lee EG, Kang SH, Kim HH, Chang YK (2006) Recovery of lactic acid from fermentation broth by the two-stage process of nanofiltration and water-splitting electrodialysis. Biotechnology and Bioprocess Engineering 11: 313-318.

22. Glassner DA, Elankovan P, Beacom DR, Berglund KA (1995) Purification process for succinic acid produced by fermentation. Applied Biochemistry and Biotechnology 52: 73-82.

23. Alvarez F, Alvarez R, Coca J, Sandeaux J, Sandeaux R, et al. (1997) Salicylic acid production by electrodialysis with bipolar membranes. Journal of Membrane Science 123: 61-69.

24. Glassner DA (1992) Process for the production and purification of succinic acid US Patent $5,143,834$

25. Wang Y, Zhang X, Xu T (2010) Integration of conventional electrodialysis and electrodialysis with bipolar membranes for production of organic acids. Journal of Membrane Science 365: 294-301.

26. Nghiem N, Davison BH, Donnelly MI, Tsai SP, Frye JG (2001) An integrated process for the production of chemicals from biologically derived succinic acid ACS Symposium Series 784: 160-173.

27. Freger V, Arnot TC, Howell JA (2000) Separation of concentrated organic/ inorganic salt mixtures by nanofiltration. Journal of Membrane Science 178 185-193.

28. Gineste JL, Pourcelly G, Lorrain Y, Persin F, Gavach C (1996) Analysis of factors limiting the use of bipolar membranes: A simplified model to determine trends. Journal of Membrane Science 112:199-208.

29. Zondervan, E, Nawaz M, de Haan AB, Woodley JM, Gani R (2011) Optima design of a multi-product biorefinery system. Computers \& Chemical Engineering 35: 1752-1766.
30. Qiu Y, Rasmuson AC (1991) Nucleation and Growth of Succinic Acid in a Batch Cooling Crystallizer. AiChE Journal 37: 1293-1304

31. Husson SM, King CJ (1999) Multiple-acid equilibria in adsorption of carboxylic acids from dilute aqueous solution. Ind Eng Chem Res 38: 502-511.

32. Song H, Lee JW, Choi S, You JK, Hong WH, et al. (2007) Effects of dissolved $\mathrm{CO} 2$ levels on the growth of Mannheimia succiniciproducens and succinic acid production. Biotechnology and Bioengineering 98: 1296-1304

33. Lin SKC, Du C, Koutinas A, Wang R, Webb C (2008) Substrate and product inhibition kinetics in succinic acid production by Actinobacillus succinogenes. Biochemical Engineering Journal 41: 128-135.

34. Blanch HW, Clark DS (1997) Biochemical Engineering. New York Marce Dekker, Inc.

35. Harris CK, Roekaerts D, Rosendal FJJ, Buitendijk FGJ, Daskopoulos P, et al. (1996) Computational fluid dynamics for chemical reactor engineering. Chemical Engineering Science 51: 1569-1594

36. Fluent F (2006) 6.3 User's Guide. Fluent, Inc.: Lebanon, NH

37. Aden A, Ruth M, Ibsen K, Jechura J, Neeves K, et al. (2002) Lignocellulosic biomass to ethanol process design and economics utilizing co-current dilute acid prehydrolysis and enzymatic hydrolysis for corn stover. NREL Technical Report, National Renewable Energy Laboratory: Golden, Colorado.

38. Sadrameli SM, Seames W, Mann M (2008) Prediction of higher heating values for saturated fatty acids from their physical properties.Fuel 87: 1776-1780.

39. Wallberg O (2005) Design of Ultrafiltration Process for Extraction of Lignin from Kraft black liquor. Internal Report, Department of Chemical Engineering, Lund Institute of Technology, Sweden: 1-9.

40. Harrison RG, Todd P, Rudge SR, Petrides DP (2003) Bioseparations Science and Engineering. Oxford: Oxford University Press.

41. Field RW, Pearce GK (2011) Critical, sustainable and threshold fluxes for membrane filtration with water industry applications. Advances in Colloid and Interface Science 164: 38-44

42. Mulder M (1996) Basic Principles of Membrane Technology (2ndedn), Klumer Academic Publishers.

43. Zheng P, Fang L, Xu Y, Dong JJ, Ni Y, et al. (2010) Succinic acid production from corn stover by simultaneous saccharification and fermentation using Actinobacillus succinogenes. Bioresource Technology 101: 7889-7894.

44. van't Riet K, Tramper J (1991) Basic Bioreactor Design. New York: Marce Dekker, Inc.

45. Lange H, Taillandier P, Riba JP (2001) Effect of high shear stress on microbia viability. J Chem Technol Biotechnol 76: 501-505.

46. Lee JM (1992) Biochemical Engineering. Prentice-Hall, Inc

47. Paul EL, Atiemo-Obeng VA, Kresta SM (2004) Handbook of industrial mixingScience and Practice.

48. Versteeg HK, Malalasekera W (1995) An Introduction to Computational Fluid Dynamics, Harlow, England: Addison Wesley Longman Limited.

49. Antoine C (1888) Tensions des vapeurs; nouvelle relation entre les tensions et les températures. Comptes Rendus des Séances de l'Académie des Sciences 107: 681-684, 778-780, 836-837.

50. Diosady LL, Puzanov T (2005) Membrane Fermentation of Lactic Acid. International Journal of Applied Science and Engineering 3: 19-25.

51. Song L (1998) Flux decline in crossflow microfiltration and ultrafiltration: mechanisms and modeling of membrane fouling. Journal of Membrane Science 139: 183-200.

52. Song $L$ (1998) A new model for the calculation of the limiting flux in ultrafiltration. Journal of Membrane Science 144: 173-185.

53. Coulson JM, Richardson JF (1991) Chemical Engineering (4thedn) Vol 2, Butterworth Heinemann.

54. Lee JW, Kwon TO, Moon IS (2004) Adsorption of mono saccharides, disaccharides, and maltooligosaccharides on activated carbon for separation of maltopentaose. Carbon 42: 371-380.

55. Uchida H, Iwai Y, Amiya M, Arai Y (1997) Adsorption behaviors of 2,6- and 2,7 
Citation: Wensel P, Yu L, Chen S (2011) Simulation with Computational Fluid Dynamics of Succinic Acid and Co-Product Biorefinery Process. J Bioprocess Biotechniq S2:002 doi:10.4172/2155-9821.S2-002

dimethylnaphthalenes in supercritical carbon dioxide using NaY-type zeolite. Ind Eng Chem Res 36: 424-429.

56. Knaebel KS (1990) A"How-To" Guide for Adsorber Design. Adsorption Research, Inc., Dublin, Ohio.

57. Sun K, Jiang JC, Xu JM (2009) Decolorization and chemical regeneration of granular activated carbon used in citric acid refining. Bull Chem Soc Ethiop 23: 29-36.

58. Ladisch MR (2001) Bioseparations Engineering. Principles, Practice, and Economics. John Wiley \& Sons, Inc.

59. Davison BH, Nghiem NP, Richardson GL (2004) Succinic acid adsorption from fermentation broth and regeneration. Applied Biochemistry and Biotechnology 114: 653-669.

60. Nam HG, Park KM, Lim SS, Mun S (2011) Adsorption Equilibria of Succinic Acid and Lactic Acid on Amberchrom CG300C Resin. J Chem Eng Data 56: 464-471.

61. Cooney DO (1998) Adsorption design for wastewater treatment CRC Press, LLC.

62. Tavare NS (1994) Industrial Crystallization: Process Simulation Analysis and Design. Plenum Press, New York.

63. Jancik SJ, Grootscholten PAM (1984) Industrial Crystallization. Delft University Press.

64. Mullin JW, Whiting MJL (1980) Succinic Acid Crystal-Growth rates in aqueoussolution. Ind Eng Chem Fundamen 19: 117-121.
65. Chang, J (2011) Indicative Chemical Prices A-Z, ICIS Chemical Business 2011.

66. Park TH, Juan H, Lim HC (1991) Theoretical-analysis of the effect of cell recycling on recombinant cell fermentation processes. Biotechnol Prog 7: 77-84.

67. Kim MI, Kim NJ, Shang L, Chang YK, Lee SY (2009) Continuous production of succinic acid using an external membrane cell recycle system. Journal of Microbiology and Biotechnology 19: 1369-1373.

68. Lee PC, Lee SY, Chang HN (2008) Cell recycled culture of succinic acidproducing Anaerobiospirillum succiniciproducens using an internal membrane filtration system. Journal of Microbiology and Biotechnology 18: 1252-1256.

69. Mhurchú JN (2008) Dead-end and crossflow microfiltration of yeast and bentonite suspensions: experimental and modelling studies incorporating the use of artificial neural networks, PhD thesis, School of Biotechnology, Dublin City University: Dublin, 1-243.

70. Corona-Gonzalez RI, Bories A, Gonzalez-Alvarez V, Pelayo-Ortiz C (2008) Kinetic study of succinic acid production by Actinobacillus succinogenes ZT-130. Process Biochemistry 43: 1047-1053.

71. Mota M, Teixeira JA, Yelshin A (2002) Influence of cell-shape on the cake resistance in dead-end and cross-flow filtrations. Separation and Purification Technology 27:137-144

72. Koyuncu I, Topacik D (2002) Effect of organic ion on the separation of salts by nanofiltration membranes. Journal of Membrane Science 195: 247-263.

73. Bellona C, Drewes, JE, Xu P, Amy G (2004) Factors affecting the rejection of organic solutes during NF/RO treatment - a literature review. Water Research 38: $2795-2809$.
This article was originally published in a special issue, Bioprocessing handled by Editor(s). Dr. Mark R. Wilkins, Oklahoma State University, USA; Stefano Curcio, University of Calabria, Italy 